\title{
The Klinsky Press Agency Finding Aid at the Art Gallery of Ontario
}

by

Lisa Yarnell, Bachelors of Fine Arts, Tufts University 2013

A thesis presented to Ryerson University

\author{
In partial fulfillment of the \\ requirements for the degree of \\ Master of Arts \\ in the program of \\ Film and Photography Preservation and Collections Management
}

Toronto, Ontario, Canada, 2015

CLisa Yarnell, 2015 
Author's Declaration

I hereby declare that I am the sole author of this thesis. This is a true copy of the thesis, including any required final revisions, as accepted by my examiners.

I authorize Ryerson University to lend this thesis to other institutions or individuals for the purpose of scholarly research.

I further authorize Ryerson University to reproduce this thesis by photocopying or by other means, in total or in part, at the request of other institutions or individuals for the purpose of scholarly research.

I understand that my thesis may be made electronically available to the public. 


\begin{abstract}
The Klinsky collection (comprised of Klinsky I and Klinsky II) contains over 20,000 press photographs from the 1930s and 1940s and was amassed by Emil Klinsky, the owner and operator of Recla, a picture distribution agency located in Amsterdam. Operating primarily during the 1930s, Klinsky at the helm of Recla, handled picture distribution in the Netherlands for numerous media agencies in Germany. The Klinsky I collection encompasses 9,236 press photographs, assembled from illustrated magazines and press agencies from the 1930s. The Art Gallery of Ontario acquired it in 2002 from the Archive of Modern Conflict. Although the Klinsky collection is one of largest photographic collection at the Art Gallery of Ontario, access to the collection is hindered by its lack of organization. The creation of a finding aid enables new access points to the collection which will facilitate and promote research. An intellectual arrangement based on 16 subject terms was implemented, and a database was created to reflect the new organization of the contents.
\end{abstract}


Acknowledgements

I would like to thank my family for their unwavering love and support. I dedicate this paper to my father who always inspired me. 


\section{Table of Contents}

Author's Declaration $\quad$ ii

Abstract iii

Acknowledgement iv

Table of Contents $\quad \mathrm{V}$

List of Illustrations vi vi v

PART I: RESEARCH PAPER

1. Introduction 1

2. Biographical Sketch 4

3. Description of Contents 8

4. Literature Survey 10

5. Methodology 19

6. Conclusion 26

Bibliography 28

Appendices

I. Historical Timeline $\quad 34$

II. Klinsky I Subject Index 36

III. Klinsky Subject Terms/Getty Concepts Conversion chart 38

IV. Selected Biographies 41

$\begin{array}{ll}\text { Illustrations } & 46\end{array}$

PART II: FINDING AID

A. Descriptive Summary 53

B. Administrative Information $\quad 55$

C. Scope and Content $\quad 56$

D. Organization and Arrangement 56

E. History of the Klinsky Collection $\quad 57$

$\begin{array}{ll}\text { F. Selected Biographies } & 58\end{array}$

G. Klinsky I Subject Terms

$\begin{array}{ll}\text { H. Related Materials } & 65\end{array}$

$\begin{array}{ll}\text { I. Notes to Researchers } & 65\end{array}$

$\begin{array}{ll}\text { J. Bibliography } & 66\end{array}$

$\begin{array}{ll}\text { K. Appendices } & 72\end{array}$

Appendices

I: Description and Instructions for Use of the Klinsky I Excel Workbook 72

II: Klinsky I Subject Terms Label Examples $\quad 75$

III: Index of Individuals with Biographical Materials $\quad 82$

IV: Klinsky I Box Location and Information $\quad 85$ 


\section{List of Illustrations}

All photographs included are courtesy of the Art Gallery of Ontario.

1. AGO ID. 2002/977, Associated Press, A view of the Eiffel Tower, 1930

2. AGO ID. 2002/5114, Alfred Eisenstaedt, A scene from the dance "Gefangene", 1932

3. AGO ID. 2002/5338, Neofot, Hallelujah! An open-air concert of the Salvation Army, c. 1931

4. AGO ID. 2002/8441, Weil van der Randen, A Douglas aircraft rest on the airfield, while a Fokker aircraft flies in distance, 1930s

5. AGO ID. 2002/5427, Mauricio Fresco, One of the main industries of Japan is the production of silk, c.1934

6. AGO ID. 2002/8411, Weil van der Randen, Pastor Perquin, founder of the Catholic Radio Broadcasting Foundation, introduces a KRO concert at the Concertgebouw in Amsterdam, January 301934

7. AGO ID. 2002/5264, Presse- Photo, The Police Summons: A psychological photo story by Dr. Thoma, c. 1932

8. AGO ID. 2002/5265, Presse- Photo, The Police Summons: A psychological photo story by Dr. Thoma, c. 1932

9. AGO ID. 2002/5263, Presse- Photo, The Police Summons: A psychological photo story by Dr. Thoma, c. 1932

10. AGO ID. 2002/5282, Alfred Eisenstaedt, Camp "Youth and the Cross", 1932

11. AGO ID. 2002/5287, Alfred Eisenstaedt, Frau Margarete Turgel: Head and reflection of the woman who created and patented a playful zoo in silver foil, 1931

12. AGO ID. 2002/5370, Eric Borchert, This picture shows what little success the French propaganda has had regarding the fall of the birth rate, 1934

13. AGO ID. 2002/3991, Transatlantic Photos, Gymnastics in the snow. A group of women exercise in the snow, not as a pastime but as a physical strength training, 1942 14. AGO ID. 2002/5005, Alfred Eisenstaedt, The Latest Vogue. Here the camera shows the skyline of Manhattan reflected in a pair of sunglasses. c. 1936

15. AGO ID. 2002/4371, Alfred Eisenstaedt, The breads are cut and formed into rows, 1930 


\section{Introduction}

The Klinsky Press Agency Collection (comprised of Klinsky I and Klinsky II) contains over 20,000 press photographs from the 1930s and 1940s and was amassed by Emil S. Klinsky, owner and operator of the picture agency Recla, which was established in Amsterdam. Operating from around 1930 to 1943, Klinsky, at the helm of Recla, handled picture distribution in the Netherlands for numerous media agencies in Germany. ${ }^{1}$ The Klinsky I collection encompasses 9,236 German press photographs that Recla distributed and sold to many popular news and illustrated magazine publications during the 1930s. The Art Gallery of Ontario (AGO) acquired it in 2002 from the Archive of Modern Conflict (AMC), and then subsequently acquired the second part of the collection, Klinsky II, in 2005. The collection contains photographs produced by the most well-known press photographers working in Germany during the 1930s. Photographic series make up the bulk of the collection; the variety of subjects covered in the picture series chronicle the rise and refinement of photo reportage.

The Klinsky Collection was separated into Klinsky I and Klinsky II by the AMC, and following this division the contents of Klinsky I were organized by agencies and creators. This arrangement by agencies and creators is similar to how the photographs were originally organized during the time Recla operated as a picture distribution agency. ${ }^{2}$ When the Klinsky I collection arrived at the AGO in 2002, further collection processing occurred. A selection of 100 photographs were removed from their original series, then matted and rehoused in flat file boxes. These photographs were selected to represent major themes and famous photographers in the collections' contents. Once a photograph is placed in a matted housing, it is AGO policy to keep it there due to cost effectiveness. As a result, the photographs in the flat files have been separated from their original order in the collection. When the collection was first accessioned into the AGO database in 2002, each photograph was assigned an AGO identification number and given a physical label displaying the number. When the AGO moved to The Museum System (TMS), their current collections system, each photograph was given a new

\footnotetext{
${ }^{1}$ Maia-Mari Sutnik, Outstanding Significance and National Importance: Klinsky Agency Archive, report (7.2002), 1 .

${ }^{2}$ Sutnik 2.
} 
accession number, which rendered the photograph's previous label ineffective. The Klinsky I collection is physically organized by individual creator or press agency, and the contents are housed in 119 boxes. Because the boxes and photographs were assigned accession numbers long after they were originally processed, and at different times, the boxes cannot easily be navigated by the accession number sequence.

Although the Klinsky collection is the largest photographic collection at the AGO, access to the contents of Klinsky I is hindered by its organization. Presently there is no navigable way to search for photographs based on subject matter. Klinsky II, the counterpart of Klinsky I, contains over 11,000 photographs. Several years ago, a PPCM graduate, Julienne Pascoe, organized its contents using a category-based finding aid. The contents of Klinsky II, although not digitized, are easily navigated through the physical organization and finding aid description of the collection.

The goal of my applied thesis project was to create a finding aid that will enable the Klinsky I collection to be more accessible for research. Several research questions were developed: Using collections management strategies, what is the best way to facilitate access to the Klinsky I collection? What is the most effective method to organize a large body of press photographs created by so many different photographers?

A finding aid is a descriptive tool, containing information that establishes control over records and facilitates their retrieval. ${ }^{3}$ The aim of this project is to create and apply terms that generally describe the contents of each photograph, and then to implement an intellectual arrangement based on those new terms to further access to the collection. A clear and well-organized descriptive arrangement will serve as a navigational roadmap for such a large collection. By analyzing and identifying the subject matter of each photograph, I was able to intellectually organize the collection without having to physically change its arrangement. ${ }^{4}$ The creation of new access points for the contents of Klinsky I allows users additional ways to search the collection. An access point is a term, or a name, through which a descriptive record can be searched for and identified by. ${ }^{5}$ The terms applied to the Klinsky I collection provide sixteen points of access to its photographs, which will allow researchers entry points that can be further used to explore

\footnotetext{
| ${ }^{3}$ Rules for Archival Description (RAD2) (Ottawa: Canadian Council of Archives, 2008), D-1.

${ }^{4}$ Ibid., D-2.

${ }^{5}$ Ibid., D-1.
} 
historical themes featured in the contents. 


\section{Biographical Sketch}

Very little information exists on the history of the Klinsky Agency collection. The three sources that contain credible information pertinent to the collection are limited in their length and scope. German Photographs of the 1930s: Royal Festival Hall, 1995 by Ian Jeffrey, a renowned curator and historian, is solely dedicated to the Klinsky Press Agency and its contents. The text was an accompaniment to a 1995 exhibition, German Photographs of the 1930s, at Royal Festival Hall in London. ${ }^{6}$ Organized by the AMC, and curated by Jeffrey, the exhibition showcased 140 photographs from the Klinsky Agency collection - it was the first time any of the collection's contents had been publicly exhibited. Jeffrey's text discusses themes he identified while processing the collection and offers some biographical information about the photographers and picture agencies featured in the exhibition. The themes identified by Jeffrey, such as the Modern Woman, Children, Modern Germany, Hard Times, Control, Technological Advancement, and Aviation are important to note because Jeffrey observed them as he processed the entirety of the Klinsky Press Agency collection. ${ }^{7}$ Certain subjects make numerous appearances in the collection contents, such as planes, zeppelins, and helicopters, which reflect the technological advances occurring in Germany during the 1930s. These photographs offer a window into the interests of both society and the photographers themselves during the time period in which they were created. ${ }^{8}$

Jeffrey briefly discusses the provenance of the collection, stating that its contents "were originally the stock of the Klinsky Agency, which was in storage near Amsterdam since the war before being acquired by the AMC." The Klinsky Agency collection moved to London in the early 1990s. At the AMC, Ian Jeffrey processed the contents of nearly 20,000 photographs. He verified the contents of the collections and, subsequently, curated the Royal Festival Hall exhibition and authored the textual accompaniment. Jeffrey writes that "the Klinsky agency which was set up in Amsterdam around 1930 and

${ }^{6}$ Ian Jeffrey, German Photographs of the 1930s: Royal Festival Hall, 1995 (London: South Bank Centre, 1995), 1.

7 Ibid., 3.

8 Ibid., 32.

9 Ibid., 8. 
had its heyday in the early '30s. It distributed pictures from Berlin agencies, and was liberal in outlook, with a strong bias towards documentary." 10

The separation of the Klinsky Press Agency collection into two parts, Klinsky I and Klinsky II, occurred at the AMC. It is unknown who decided or assisted in the separation process of the photographs into groups, but it is acknowledged that Klinsky I, which is smaller, contains the top-tier imagery, while Klinsky II, with subjects typically relating to commercial means, would be considered stock photography in present day terms. ${ }^{11}$

Maia-Mari Sutnik, Curator of Photography at the AGO, visited the Klinsky collection at the AMC and was responsible for its two-part acquisition-Klinsky I came to the AGO in 2002, and Klinsky II arrived in 2007. During the acquisitions process, Sutnik authored a research report for the Canadian Cultural Property Export Review Board. Her report served as the primary resource for tracing the history of the Klinsky Agency.

Verifiable information on the life of Emil S. Klinsky is rare, and one source was located during the research process that discussed his life specifically - a newspaper article written by Louis Zweers in 1996, and translated from Dutch into English with Google Translate. ${ }^{12}$ The article discusses the life of Emil S. Klinsky and lays claim that Klinsky was able to own and operate his photo agency due to his collaboration with the Nazis. Zweers provides no further sources of reference to substantiate the claim that Klinsky worked with the Nazi party. The article's credibility is compromised by potential translation inaccuracies and unsubstantiated claims by its author.

Due to the limited information on the Klinsky Press Agency collection, Emil S. Klinsky, or Recla, research on how other European picture agencies operated was critically needed for this project. A picture agency's primary task was to work with both photographers and other picture agencies to sell and distribute photographs to publications. ${ }^{13}$ The relationship between photographers and agencies were of mutual benefit, as described by historian Dr. Cynthia Smith, whereby photographers relied on

\footnotetext{
10 Ibid., 13.

11 Ibid.

${ }^{12}$ Louis Zweers, "De Zwerftocht van Klinsky's Foto-archief," Trouw (May 4, 1996).

${ }^{13}$ Cynthia Zoe Smith, Emigré Photography in America: Contributions of German Photojournalism from Black Star Picture Agency to Life Magazine, 1933-1938. (PhD diss., University of Iowa, 1983), 111.
} 
agencies to direct their pictures to the best magazines and score them the highest picture price. ${ }^{14}$ Picture agencies, for a fee, would provide bookkeeping services for the photographers they represented, and put photographers in contact with publications and clients. ${ }^{15}$ Photographers benefitted from working with picture agencies because they were able to pursue assignments at their leisure while their agencies handled the publishing details. ${ }^{16}$

Ute Eskildsen's Willi Ruge and Fotoaktuell: Adventures for the Press was another informative text. German photographer Willi Ruge (who established his own picture agency, Fotoaktuell, in Berlin in 1910) worked with the Klinsky Press agency during the 1930s. ${ }^{17}$ The Klinsky I collection contains several hundred photographs by Ruge. As owner and operator of his own picture agency, his picture series reveal his own personal narratives. ${ }^{18}$ Ruge's photographs display several of the themes Jeffrey identified in the Festival Hall publication, including multiple photo series of sporting events and planes. ${ }^{19}$ Ruge is best known for his daredevil tendencies as a photographer - one of the photo series he made, he parachuted from an airplane, and several of those photographs are included in the Klinsky I collection. ${ }^{20}$ Ruge, unlike the majority of photographers featured in Klinsky I, worked in Germany for the entirety of the 1930s. His work captures a very tumultuous fifteen-year period of Nazi history. The Klinsky Press Agency collection contains work from many well-known photographers and picture agencies, such as Alfred Eisenstaedt, Ilse Steinhoff, Willem Van de Poll, Keystone Press Agency, Dephot, Associated Press Berlin, and many other notable sources. ${ }^{21}$

Klinsky, as owner of Recla, would have adhered to certain laws and been subject to some government scrutiny before the invasion of the Netherlands, and he certainly would have acted in compliance with sanctions imposed by the Nazis after their invasion on May 10, 1940. Recla worked with a variety of German picture agencies, so it can be

\footnotetext{
${ }^{14}$ Smith, 100 .

${ }^{15}$ Ibid.

${ }^{16}$ Ibid., 186.

${ }^{17}$ Ute Eskildsen, "Willi Ruge and Fotoaktuell: Adventures for the Press," in Object:Photo. Modern Photographs: The Thomas Walther Collection 1909-1949. An Online Project of The Museum of Modern Art (New York: Museum of Modern Art, 2014), 2.

18 Ibid., 3.

19 Ibid., 5.

${ }^{20}$ Ibid., 6 .

${ }^{21}$ See Appendix III for biographies.
} 
presumed that those picture agencies may have undergone some amount of government censorship. The issuing of laws pertaining to German media began in 1933 and they were not abolished until after Germany surrendered to the Allies on May 7, 1945. Although the extent of media sanctions experienced by German picture agencies can only be estimated, it is important to identify the laws issued during this time period. ${ }^{22}$

\footnotetext{
${ }^{22}$ See Appendix I for media censorship timeline.
} 


\section{Description of Contents}

The collection contains 9236 silver gelatin prints, and most are $18 \times 24 \mathrm{~cm}$. Because these photographs were created with the intent of publication, the majority of the photographs in the collection contain their original captions, credit stamps, and agency code numbers, most of them written in German. The title and caption were typed on a piece of thin tissue-like paper that was taped or glued onto the verso of each photograph. Sometimes the title would be denoted with a line under the text that was intended as the title, but most of the time, the first line of the text would be assumed as the title. The ideal way to understand the collection would be to see a photograph printed in an illustrated magazine from the time period - the experience of viewing thousands of photographs with their original titles and captions reveals the interests of the time period. ${ }^{23}$ Maia-Mari Sutnik writes, "The attached captions increase the potency of the images with narratives or descriptions. In combination they reveal an exceptional range of photographic qualities; from visual communication and technical trends, to new camera uses, lighting effects, photo-telegraphy, which enhanced the interest of individual expressions." 24

Picture agencies applied different stamps and stickers to the backs of photographs denoting what agencies they had been distributed through. Over 1000 photographs have specific dates stamped on their versos. Four different versions of the Recla stamp can be seen through the stamping of the versos. ${ }^{25}$ Recla handled picture distribution for many successful Berlin-based picture agencies, including Keystone Press Agency, Dephot, Associated Press Berlin, and Presse-Photo. Additionally, Recla represented several international agencies, such as Pix Publishing, and foreign photographers like John Gutmann and Ihee Kimura. The photographs represent both German and international interests, and their contents display a unique mixture of news and narrative picture press photography. ${ }^{26}$ One of the most significant components of the collection is the numerous

\footnotetext{
${ }^{23}$ See Illustrations 2-6.

${ }^{24}$ Sutnik, 4.

${ }^{25}$ See Illustrations 2-4.

${ }^{26}$ Ibid.
} 
photographs documenting German society throughout the 1930s which number in the thousands. $^{27}$

The subject matter featured in the photographs varies greatly, but certain themes can be seen throughout the collection as discussed by Jeffrey ${ }^{28}$. Serial photography, as defined by Dr. Smith, is also referred to as photo essays or photo series, which describes a series of photographs based on a related theme or event that was intended to be read for narrative content. ${ }^{29}$ Although it is not known whether the photographs in the Klinsky I collection were ever printed as photo essays, the contents feature numerous examples of serial photographs. "Slice of Life" photographs were a series of photographs that described common everyday life themes, as identified by both Jeffrey and Sutnik. ${ }^{30}$

27 Ibid.

${ }^{28}$ Jeffrey, 8 .

${ }^{29}$ Smith, 82.

${ }^{30}$ See Illustrations 7-9. 


\section{Literature Review}

In organizing the Klinsky collection and creating a finding aid, an examination of literature pertaining to the history of photojournalism and collections management is necessary. Divided into three sections, this survey first reviews texts written on the history of press photography in the Weimar Republic. It is important to review these histories in order to gain some understanding of context in which photography of that era developed. The second section evaluates articles and books describing photographic agencies, which developed alongside press photography. Finally, the third section examines resources on collections management and intellectual arrangement.

\section{(A) History of Press Photography in the Weimar Republic}

Photography and Society written by Gisèle Freund, a photojournalist and historian of documentary photography, provides a detailed history of press photography in the Weimar Republic and discusses the factors that influenced the birth of modern photojournalism. Freund describes how the postwar climate led to the transformation of Berlin, the capital of the Weimar Republic. ${ }^{31}$ It became the center of intellectual and artistic movements during this time period. Illustrated magazines and newspapers became the symbol for the liberal spirit of the era and were popular both in the capital and all over Germany. ${ }^{32}$ Approximately 600 to 800 newspapers were using photographs and texts regularly to create picture stories in the $1920 \mathrm{~s}$. $^{33}$ The popularity of picture stories skyrocketed the sales of illustrated magazines and newspapers alike. The two most popular illustrated magazines were Berliner Illustrierte Zeitung and the Münchner Illustrierte Presse. ${ }^{34}$ At the height of its success in 1931, Berliner Illustrierte Zeitung had a press run of nearly two million copies, which Freund cites as "the beginning of the golden age of modern photojournalism". ${ }^{35}$ She also discusses the development of the photo story becoming a key feature in illustrated magazines. She identifies Münchner Illustrierte Presse editor-in-chief, Stephan Lorant, as the individual who helped refine the

${ }^{31}$ Gisèle Freund, Photography \& Society (Boston: D.R. Godine, 1980), 117.

32 Ibid., 125.

33 Ibid., 117.

${ }^{34}$ Ibid., 118.

35 Ibid., 117. 
incorporation of the photographic essay by reformatting layouts and captions to better narrate photographic sequences. Freund singles out the efforts of one editor as the individual responsible for the development of the entire genre of photo reportage, but other texts on the history of photojournalism discuss multiple photographic editors.

The Space Between the Pictures: Photography, Literature and the Late-Weimar Photo Essay by Dr. Daniel Magilow examines specific photo essays published in the Weimar Republic and describes how social, economic, cultural, and aesthetic factors impacted the way the pictures were published. Magilow offers a fascinating analysis of political influences on illustrated magazines by focusing on a singular event - the death of Gustav Stresemann and how photo reportage differed significantly in each publication depending on their political alignment. He writes that it was in an effort to surpass the competition that magazine editors looked for new ways to intrigue readers, and their efforts resulted in the development of the modern photo essay where "with flashy formal techniques, an editor can highlight certain aspects of this continuum that would otherwise rush by in the accelerated flux of modem life." 36 The author observes that despite the different ideological foundation of each publication, illustrated magazines had much in common: "They were produced, reproduced, distributed, and consumed in the same ways. To publish enormous press runs of illustrated magazines and sell them in the same kiosks for similar prices, for instance, the Left and the Right used the same production technologies and distribution networks of capitalist media culture. Ideological rivals regularly printed similar or even identical wire service photographs, although they changed their political connotations with different captions." 37 Although Klinsky did not work for any of the mentioned illustrated magazines, the text is an invaluable tool for understanding the social, economic, and political motivations responsible for the rise of photojournalism during the Weimar Republic.

In Kiosk: A History of Photojournalism, authors Robert Lebeck and Bodo von Dewitz chose to reproduce original picture stories and layouts from newspapers and magazines. Chronicling the history of photojournalism with images directly from the pages of publications being discussed, the imagery provides visual evidence to further

\footnotetext{
${ }^{36}$ Daniel H. Magilow, The Space Between the Pictures: Photography, Literature, and the Late-Weimar Photo-Essay (Princeton University, 2003), 79.

${ }^{37}$ Ibid., 82.
} 
substantiate the arguments made by Lebeck and von Dewitz. Featuring layouts published in the late 1920s to early 1930s, from Die Woche, Berliner Illustrierte, Die Dame, and Münchner Illustrierte Presse, the authors illustrate how magazine formats changed to incorporate photographic essays. Kurt Korff, editor for Berliner Illustrierte Zeitung, and Stephan Lorant are recognized as the editors responsible for featuring photographic essays in their magazines. ${ }^{38}$ The authors include an image of an article titled "Eine neue Künstler-Gilde. Der Fotograf erobert Neuland,"39 featured in a 1929 issue of Uhu. The article describes the skill set necessary for working photojournalists, using photographers such as James Abbe, O.E. Hoppé, André Kertész, László Moholy-Nagy, Martin Munkácsi, Albert Renger-Patzsch, Erich Salomon, and Sasha Stone as examples. ${ }^{40}$ What the article proves is that the skills necessary to be a successful photojournalist had changed drastically. The authors maintain that the best-known photojournalists of the Weimar Republic were not trained press photographers, but, almost without exception, had an academic background and had acquired their photographic skills as amateurs. ${ }^{41}$ Although neither Klinsky nor any of the publications he worked for are mentioned, having acted as the photo editor for two years at Associated Press Berlin, Klinsky would have certainly performed similar tasks to Korff and Lorant, in reformatting page layouts to accommodate photo essays.

All of the texts analyzed echo similar beliefs on the history of photojournalism in the Weimar Republic. Editors of illustrated magazines played a critical role in the development and incorporation of the photo story. Berliner Illustrierte Zeitung and the Münchner Illustrierte Presse, and their respective editors Kurt Korff and Stephan Lorant, are the most widely discussed examples of individuals who changed layouts and formats to incorporate photo essays. The skills of photographers working during the $1920 \mathrm{~s}$ and 1930s were that of educated individuals who were not professionally trained; amateur photographers who improved their skills as their careers progressed.

\footnotetext{
38 Robert Lebeck and Bodo Von Dewitz, Kiosk: A History of Photojournalism (Göttingen: Steidl, 2002), 112.

39 (Which, translated, means: “A new artists' guild. Photographers conquer new territory.”)

40 Ibid., 130.

41 Ibid., 112.
} 
(B) Photographic Agencies

German historian Hendrik Neubauer examines the establishment and development of the Black Star photographic agency in his book Black Star: 60 Years of Photojournalism. Although the Black Star agency was based in America, the book still proves useful in describing the structure and organization of a successful picture agency. The Black Star agency imitated the structure of the Berliner Illustrierte Zeitung. Korff, previously the editor-in-chief of the Berliner Illustrierte Zeitung, introduced the highly systematic and organized structure of German photographic agencies to the Black Star agency, and later to Life magazine. ${ }^{42}$ Neubauer's book describes the inner workings of the Black Star agency, including methods of payment and types of photographer contracts. His detailed analysis of Black Star can be used as a point of reference when describing the structure of German photographic agencies.

In the article "Constructing Photojournalism in Weimar Germany, 1928-33," author Hanno Hardt, a renowned historian of communication, discusses how photojournalism was used for political propaganda both before and after the rise of Nazism in Germany, and how factors such as advancements in distribution technology and the relationships between publishers, editors-in-chief, picture editors, and photographers, all contributed to photography being used as a political weapon. Included in the article is a description of typical daily distribution activities at the photo agency Pacific \& Atlantic, as described by a photographer who worked in the Berlin bureau in $1930 .{ }^{43}$ Klinsky began working as photo editor at the agency during the same year. Each day, 5 to 15 photographs were selected, and then 80 copies were made of each for general shipment, and an additional 30 copies for the London, Paris, and New York offices of the Associated Press. ${ }^{44}$ Hardt's article describes the staggering amount of copies made of a single photograph, which explains why there are many duplicate photographs within the Klinsky collection. Hardt maintains that before 1933, photojournalism reflected a middle class worldview that had little to do with the actual conditions of society. ${ }^{45}$ The needs and interests of German magazine editors determined the direction and content of photo

\footnotetext{
${ }^{42}$ Hendrik Neubauer, Black Star: 60 Years of Photojournalism (Köln: Könemann, 1997), 11.

${ }^{43}$ Hanno Hardt, "Constructing Photojournalism in Weimar Germany, 1928-33," Communication Review 1, no. 3 (1996): 376.

${ }^{44}$ Ibid., 377.

${ }^{45}$ Ibid.
} 
reportage. Thus, picture agencies were in constant competition with each other, vying for the employment of each domestic publication including the daily presses and picture magazines. ${ }^{46}$

Photographer and author, Tim Gidal wrote about his experiences as a photojournalist in Germany in his book Modern Photojournalism: Origin and Evolution, 1910-1933. Gidal draws attention to the establishment of two photographic agencies in 1928, Dephot and Weltrundschau. In contrast to other picture agencies that only dealt with photographic distribution, these new agencies dealt with the production and coordination of photo reportage in addition to distribution. ${ }^{47}$ The directors of these agencies played a much larger role in the composition and placement of photo reportages in publications, coordinating photo essays with both editors and reporters from illustrated magazines or newspapers. ${ }^{48}$ In 1931, Keystone and Associated Press Berlin (formerly Pacific \& Atlantic) began production of their own photo reportage, in addition to distribution of single pictures. ${ }^{49}$ Gidal's book provides a rare look into working photographers lives both before and during Hitler's reign in Germany. His examination of other working photographers is fairly limited, he tends to single out individuals whom he personally knew, but his book is still a valuable research tool in its first person account of the time period.

\section{(C) Finding Aid}

Research on intellectual arrangement and how to create a finding aid provided numerous resources pertaining to archival practices. Many texts stated that every institution has its own adaptations of standards and practices of collections management. Familiarization with the standards of the Rules for Archival Description (RAD) was essential for the development of a finding aid that would meet Canadian archival and AGO standards. RAD standards are defined in a manual published by the Canadian Committee of Archival Description in 1990 - they are an established national standard

\footnotetext{
${ }^{46}$ Ibid., 392.

${ }^{47}$ Ibid., 18.

${ }^{48}$ Ibid.

${ }^{49}$ Ibid., 19.
} 
for rules of archival description used in museums and archives alike. ${ }^{50}$ Last revised in 2008, the manual is now endorsed by the Bureau of Canadian Archivists and includes a statement of principles and a new chapter pertaining to discrete items. ${ }^{51}$ While RAD has clearly defined standards, it does allow for different vocabularies or terms to be used within its rule system, such as the Getty and Library of Congress vocabularies.

The Getty authority includes four vocabularies: The Art and Architecture Thesaurus (AAT), the Getty Thesaurus of Geographic Names (TGN), the Union List of Artist Names (ULAN), and the Cultural Objects Name Authority (CONA). These controlled vocabularies were developed for the museum community to establish standards in information description by defining terminology used for cataloguing, retrieval, and research. AAT uses three types of relationships to structure itself as a thesaurus, the equivalence relationship, the hierarchal relationship, and the associative relationship. These three controlled relationships allow for the thesaurus to grow infinitely by incorporating more terms. Thousands of terms are added annually-in May 2015, AAT contained a total number of 353,285 terms. $^{52}$ The amount of terms is always growing to fit the needs of its users, including members of museums, libraries, archives, conservation specialists, and research communities. ${ }^{53}$

In MRM5: Museum Registration Methods, archivist K. Sharon Bennett lists facets of data that must be included in a finding aid. Information on the creator, volume of material, types of records, intellectual arrangement, and condition statement should all be contained within the finding aid. Although these requirements are simple, Bennett does not offer detailed explanations of any of the categories. A limitation of the book is that its publisher was the American Association of Museums and, as a result, several of the procedures covered by Bennett are only applicable to American institutions.

Guidelines For Formulating Subject Headings For Archival Collections by Tim Thompson, Matt Carruthers, and Natalie Bauer, provides numerous examples on how to

\footnotetext{
${ }^{50}$ Rules for Archival Description (RAD2) (Ottawa: Canadian Council of Archives, 2008).

51 Ibid.

52 "AAT: Frequently Asked Questions (Getty Research Institute)," Getty Art and Architecture Thesaurus, Online (2015), 1.

53 Ibid.
} 
create subject headings based on content. ${ }^{54}$ Written by University of Miami librarians, the examples still proved informative in their discussion of various aspects that need to be considered when describing the subject matter of photographs. ${ }^{55}$ Cataloging Historical Photographs in Olivia is an excellent reference source discussing rules and practices of the Library Preservation department at Harvard University. ${ }^{56}$ The guidelines for processing photographs can be applied to the AGO or any other institution that uses the Getty standards. The text also provides a number of additional sources pertaining to cataloguing photographs. Subject Indexing for Pictures: An Overview by Helena Zinkham, chief of Photographs \& Prints division of Library of Congress, presents a concise checklist of questions that should be answered when determining subject headings for photographs. ${ }^{57}$ Although written about Library of Congress subject headings terms and practices, the questions outlined by Zinkham are applicable to any vocabulary system. Archivists Mary Lynn Ritzenthaler and Diane Vogt-O'Connor detail the particular needs of photographs within an archive in their book Photographs: Archival Care and Management. The book details the process of consideration and evaluation necessary in the creation of a finding aid, as well as discusses the importance of maintaining original order in collections. The authors write that both the needs of the collection and its institution govern the content and layout of a finding aid. ${ }^{58}$ The text offers a very thorough analysis of different identification elements and how they can be used to structure a finding aid. The text is informative and uses excellent examples to demonstrate how to structure a finding aid for small collections. Since the text makes references to collections management on a museum level, where the collections are typically quite large, there should have been discussion addressing large collections with over 5,000 items.

Published in 2014, Digital Preservation for Libraries, Archives, and Museums by Corrado and Moulaison, offers the most current analysis of various digital information

\footnotetext{
54 Tim Thompson, Matt Carruthers, and Natalie Bauer, Guidelines For Formulating Subject Headings For Archival Collections (Miami: University of Miami, 2013), 3.

55 Ibid., 8.

${ }^{56}$ Cataloging Historical Photographs in Olivia (Cambridge, MA: Harvard University, 2008), 15.

${ }^{57}$ Helena Zinkham, Subject Indexing for Pictures: An Overview (Washington DC: Library of Congress, 2004), 1.

${ }^{58}$ Mary Lynn Ritzenthaler and Diane Vogt-O'Connor, Photographs: Archival Care and Management (Chicago: Society of American Archivists, 2006), 192.
} 
systems. ${ }^{59}$ Written by two library and information science specialists, the text identifies three aspects that must be concurrently considered in digital preservation: management, technology, and the content of the collection. The chapter "File Formats and Software for Digital Preservation" is dedicated to in-depth analysis of different types of file formats and discussion of the benefits and disadvantages pertaining to each kind ${ }^{60}$ Discussion and analysis of Microsoft Excel software capabilities for small-scale databases influenced the decision to utilize Excel to make the finding aid database. ${ }^{61}$ Excel is easily understood and is a familiar software that is updated frequently and can be stored and/or recovered from the Microsoft cloud

Getty Research Institute cataloguer, Mary S. Woodley, addresses the development and migration of metadata in "Crosswalks, Metadata Harvesting, Federated Searching, Metasearching: Using Metadata to Connect Users and Information." Woodley discusses the issues encountered when institutions convert data or change data systems. Her analysis and recommendations on metadata input provide useful tips on how to effectively use metadata to create files that can survive a system conversion or migration. Although the article does not discuss The Museum System software specifically, the issues described are applicable to any digital database.

Two finding aid projects completed by former Photographic Preservation and Collections Management graduates proved to be useful resources for models of finding aids. An excellent starting point was Finding Wolff: Intellectually Arranging The Werner Wolff Fonds at the Ryerson Image Centre by Sara L. Manco, which detailed the creation and organization of a finding aid for a fond containing over 1,300 items. ${ }^{62}$ Rebecca Madamba's thesis, The Schostal Collection: A Finding Aid for The Schostal Agency Collection at the Art Gallery of Ontario, discusses the physical arrangement and organization of a large press collection of over 4,000 photographs. ${ }^{63}$ Madamba's thesis

\footnotetext{
${ }^{59}$ Edward M. Corrado and Heather Lea Moulaison, Digital Preservation for Libraries, Archives, and Museums (Rowman \& Littlefield, 2014), 7.

${ }^{60}$ Ibid., 143.

${ }^{61}$ Ibid., 140.

${ }^{62}$ Sara L. Manco, "Finding Wolff: Intellectually Arranging the Werner Wolff Fonds at the Ryerson Image Centre" (master's thesis, Ryerson University, 2012).

${ }^{63}$ Rebecca Madamba, "The Schostal Collection: A Finding Aid for The Schostal Agency Collection at the Art Gallery of Ontario" (master's thesis, Ryerson University, 2014).
} 
has been useful because the contents and number of items in the Schostal collection are similar to that of the Klinsky collection, and both belong to the same institution.

After consulting these resources, it is clear that finding aids must reflect both the collection and its institutions needs, as well as adhere to the standards set by RAD. 


\section{Methodology}

My research on intellectual arrangement and how to create a finding aid provided numerous sources on archival practices. Echoed throughout all texts was that every institution has its own standards and practices of collections management. Becoming familiar with the standards of RAD and the Getty vocabularies was essential in order to develop a finding aid that would meet Canadian and AGO standards.

The Klinsky II collection finding aid and physical organization of its contents was the most influential source in the development of the finding aid for Klinsky I. Former PPCM graduate and current PPCM instructor Julienne Pascoe processed and organized the contents of Klinsky II in 2007. Physically arranging over 11,000 photographs by creator then subject, only 15 terms were used to organize the entire collection. The Klinsky II finding aid terms demonstrate how broad descriptions can effectively sort a large collection into smaller navigable groupings.

Introduction to Controlled Vocabularies: Terminology for Art, Architecture, and Other Cultural Works by Patricia Harpring, Managing Editor at the Getty Research Institute, was instrumental in my understanding of how vocabulary informs finding aids. Harpring's text focuses on dissecting the relationships between vocabulary and collection management in museums. Analyzing different types of Getty vocabularies including the AAT, the TGN, the ULAN, the CONA, and Categories for the Description of Works of Arts (CDWA), Harpring meticulously examines each type and describes scenarios of their usages. ${ }^{64}$ Chapter 8 focuses on the application of index terms to collections, and the author's explanation of the process was a valuable resource to consult before applying index terms to the contents of the Klinsky collection. ${ }^{65}$

Basic RAD: An Introduction to the Preparation of Fonds- and Series-level Descriptions Using the Rules for Archival Description by archivist Jeff O'Brien was one of the primary sources I consulted to better my understanding of $R A D .{ }^{66}$ Published by the Canadian Council of Archives, the text includes explanations and examples of $R A D$

\footnotetext{
${ }^{64}$ Patricia Harpring, Introduction to Controlled Vocabularies Terminology for Art, Architecture, and Other Cultural Works (Los Angeles, CA: Getty Research Institute, 2010), 14.

${ }^{65}$ Ibid., 166.

${ }^{66}$ Jeff O'Brien, Basic RAD: An Introduction to the preparation of fonds- and series-level descriptions using the Rules for Archival Description (Regina: Saskatchewan Council for Archives and Archivists, 1997), 4.
} 
usages for public Canadian institutions. The text also discusses the benefits of finding aids, including the elements that should be used for description at different levels of archival arrangement, e.g., fonds, series, files, items. This text provides both informative explanations of RAD rules and descriptive examples of how RAD elements should be used. Archives and Manuscripts Processing Manual by Ann E. Hodges and Brenda S. McClurkin was another source I referenced and consulted frequently while developing the Klinsky I finding aid. ${ }^{67}$ Published by two librarians working in Special Collections at Arlington Libraries at University of Texas, this manual offers a step-by-step explanation of how to process, describe, record, and catalogue items. Although the section devoted to creation and implementation of a finding aid is brief, the authors explain every section necessary in a finding aid using Getty vocabularies. ${ }^{68}$ The manual also includes a sample finding aid for reference. This manual was an excellent resource for understanding the necessary facets of a finding aid and the correct terminology needed for each section.

\subsection{Description of the Collection}

As mentioned previously, the Klinsky I collection is physically organized by creator and/or picture agency and its contents are physically housed in 119 boxes in the Prints and Drawings Vault at the AGO. Because the boxes and photographs were assigned accession numbers long after they were originally processed, and at different times, the boxes cannot easily be navigated in sequence. Although one can search and view all the records for Klinsky I in chronological order in TMS, the records do not contain enough information to conduct a search based on subject. All of the electronic records for Klinsky I are listed by their alternative titles instead of their formal titles. In TMS, usage of alternative titles is necessary to display the translation of the title into English. Because so little information is revealed by the electronic records, and less than 100 photographs have been digitized, the subject matter of the photographs is not accurately described or represented. Although some titles might allude to the subject of a photograph, there is no navigable way to sort through the collection for a specific subject without physically opening up the boxes and visually searching for a subject.

\footnotetext{
${ }^{67}$ Ann E. Hodges and Brenda S. McClurkin, Archives and Manuscripts Processing Manual, 6th ed. (Arlington, TX: Special Collections Division, the University of Texas at Arlington Libraries, 2011), 35. 68 Ibid., 107.
} 
During the summer of 2014, Elizabeth Larew and I created and inserted new labels generated by TMS for every photograph in the Klinsky I collection. As we reviewed and updated TMS records for each photograph, I observed that although the physical organization of Klinsky I suits its contents, little information is given about the photographs themselves from its present organization. The TMS records for the majority of the photographs reveal very little about the subjects of the images. A non-Germanspeaking individual catalogued the collection at a time before language translation software was easily available, thus the task of translating German captions was extremely difficult. Most of the files have blank inscriptions and description fields.

The Klinsky I finding aid organizes photographs by both date and subject matter. I first developed 16 terms that I used to organize the collection then applied terms to each photograph based on their contents. I applied these terms in an Excel database that I created and then later applied similar Getty AAT terms in TMS.

\subsection{Organization}

A methodology was established in order to ensure and guide the success of the organization process. The first rule decided upon was that each photograph within a series must be filed in the same categories and not split from its sequence. This rule was established to respect and maintain the original order of images. One of the RAD principles of archival arrangement is respect des fonds, which means that respect must be given to the original organization of the collection or image series. ${ }^{69}$ Although the Klinsky collection is not in its original order, protection of any remaining series-level arrangement must be maintained to ensure as much of the original order and context remains intact. When applicable, image files will be further organized within their designated category by physical box location. For example, if a group of images share the same creation date and category, the files will be listed in order of their accession number, which corresponds to the order the photographs are physically organized in within their boxes. The categories used comply with the subject standards outlined by

${ }^{69}$ Rules for Archival Description (RAD2) (Ottawa: Canadian Council of Archives, 2008), D-8. 
Getty standards, and the terms applied to the records in TMS are in compliance with the Getty AAT. ${ }^{70}$

\subsection{Subject Terms}

In the TMS database, each image file contains a subject terms field. The image files in TMS have been updated to contain terms that indicate each photograph's designated categories. Adding terms to each file enables TMS users to use these terms to limit and improve searches results within the Klinsky I files. A list containing all of the terms will be presented in the form of an electronic Word document, along with a physical list, which will be provided as an additional accompaniment to the finding aid.

The decision of what subject terms to use when organizing the Klinsky I finding aid was significantly influenced by the terms used in the physical organization of Klinsky II. That collection is physically organized by 15 subject terms that are based on the Getty AAT standards. When deciding on terms to use in the intellectual arrangement for the Klinsky I collection, the decision was made to use the majority of the same terms in order to promote cohesiveness between the two parts that make up the Klinsky collection in its entirety.

The differences between the two subject indexes are minimal, the Klinsky II subject term of Animals was removed and two new subject terms, Women and Celebrity, were added to the Klinsky I finding aid. The addition of the terms Woman and Celebrity was a necessary variation from the Klinsky II subject terms. Because Klinsky II was physically organized by its terms, the term Woman would have been too large of a subject by which to physically organize the contents. I decided to add the term after reading Jeffrey's Festival Hall publication, which highlighted the theme of the modern liberated woman as a concept that was considered new and fascinating during the 1930s in Europe. ${ }^{71}$ The Modern Woman was a popular subject in illustrated magazines and there are many photographs dedicated to the theme in the Klinsky collection. ${ }^{72}$ I also added the term Celebrity. This term was necessary because I found a large amount of photographs whose subject matter pertained to celebrities, including film stars and

\footnotetext{
${ }^{70}$ Patricia Harpring, Introduction to Controlled Vocabularies Terminology for Art, Architecture, and Other Cultural Works, 48.

71 Jeffrey, 18.

72 Ibid.
} 
athletes. Because my organization is intellectual, the usage of additional terms can occur with relative ease.

The goal of applying subject terms to each record is to implement a way to sort through thousands of images based on their content. Because I abided by the rule not to separate series of photographs, instead adding multiple subject terms when necessary, some photographs may not always reflect the best description of their subject matter. If the entire collection was divided by the 16 terms, each subject would contain 579 photographs. Nearly 600 images per term is still fairly large, which is why applying multiple terms to images helps to narrow down subject matter search results.

\subsection{Process}

In TMS I conducted a search for all records containing Klinsky in the constituent field. I recorded the number of files the search yielded (9355), then conducted a second TMS query, searching by location, to confirm the same number of records. I then created an object package containing all the records so after the sorting ended I could easily pull up the files in TMS. In TMS I selected R\&R Location View, which contained multiple fields of information including current location. Using the multiple sort option, I then selected current location and accession number sort. This sorted the records into their current location by box and then organized the records by their accession numbers. The order I implemented in TMS mimics the physical arrangement of the Klinsky I photographs. Some boxes in Klinsky I were accessioned at different times so organizing the files by accession number only did not reflect their physical order in box location. Then I exported the contents list into Excel. The Excel spreadsheet contains each data field that the file contained in TMS, so no information was lost in the migration.

After creating my Excel workbook, I began the process of visually scrutinizing and then applying terms to each photograph in the collection. After completing this task, I returned to TMS and sorted each record into 16 different object packages, each one labelled with a Getty term. After completing the sorting process of each record into one or multiple object packages, Liana Radvak, Manager of Collections Information at the AGO, batch updated the records in the object packages to reflect the terms I had applied. Now, when a user conducts a constituent term query, for instance, using the term 
"Politics", all records from the Klinsky I collection with this label are contained in the search results.

\subsection{Presentation of Finding Aid}

The finding aid was generated in both physical and digital formats. The physical finding aid is contained in large binders, which hold printouts of the Excel spreadsheets. The pages of the finding aid are organized by category, chronology, then creator. The finding aid is also available in a digital file format so that access to it isn't limited by physicality, and is presented in an Excel workbook. This additional digital format was necessary because the terms applied to the records are the same terms used in the physical organization of the Klinsky II collection and utilizes terms specific to the collection. Also the Excel workbook allows for users to change their search results based on terms and chronology, an option that TMS doesn't provide. Furthermore, the Excel file can be accessed by anyone, while TMS can only be accessed by employees of the AGO.

\subsection{Description of Finding Aid Sections}

Evaluation of many archival processes and standards sources occurred before the physical structure of the Klinsky I finding aid was decided upon. The sections included were selected based on their compatibility with the AGO's current archival practices, in addition to their synchronicity with TMS and RAD standards.

\section{A. Descriptive Summary:}

Contains basic information pertaining to the collection. It includes the title proper, class of materials, dates of creation, extent of descriptive unit, administrative history and biographical sketch, then custodial history, scope and contents note, creator information, title of the collection, dates that the collection spans, a brief abstract describing the contents, the physical extent of collection, and the language of the materials.

\section{B. Administrative Information:}

Discusses the AGO's policies on access, restrictions, and copyright pertaining to the collection, and provides contact information for the institution. 


\section{Scope and Content:}

Identifies the origins and nature of the collection, then briefly discusses prominent subject matter and the extent of the contents.

D. Organization and Arrangement:

Explains the physical organization of the Klinsky I collection, as well as discusses the intellectual arrangement of the contents.

E. History of the Klinsky I Collection:

Includes biographical information about Emil S. Klinsky, the provenance about the Klinsky collection.

F. Selected Biographies:

Discusses biographical information limited to photographers and photographic agencies that have contributed over 100 photographs to the collection.

G. Klinsky I Subject Terms List:

Contains the terms list that reflects the intellectual arrangement implemented.

H. Related Materials:

Describes pertinent materials related to the Klinsky I collection.

I. Notes for Researchers:

Directs researchers to access the physical boxes to view both the content lists and location list provided. It also describes how to navigate and access the digital database.

\section{J. Bibliography}

K. Appendices 


\section{Conclusion}

Presently the Klinsky I finding aid project is complete and exists in three forms: two digital formats and one physical housing of several binders that contain printouts of the Excel workbook. Each record in TMS has been separated into an object package and is waiting to be batch updated with their designated Getty AAT terms, after which any search query conducted by terms will retrieve results based on the applied terms. There is also an Excel workbook that contains similar subject terms applied to each record in TMS - the difference between the two digital components is that in TMS the terms used are Getty AAT, while the terms used in the Excel workbook are the same terms used for the physical organization for the Klinsky II collection.

The goal of this applied thesis project was to promote access to the Klinsky I collection. Now completed, the Klinsky I finding aid will provide new access points to the contents, promoting further research of this historically significant press photography archive. Enhanced access to the Klinsky I content will allow further investigation for both photographic historians and researchers alike. Both parts of the Klinsky Press Agency collection, Klinsky I and Klinsky II, now have finding aids in place to help users navigate their contents.

In terms of further steps that could be taken to improve the collection overall, digitization aspects should be considered. Creating an electronic version of the Klinsky II finding aid would allow researchers to grasp the extent of the entire Klinsky collection. In addition, further research on the biographic information for all contributors to the collection should be considered. Presently, only one binder exists containing pertinent biographic information for prominent contributors to the contents of the Klinsky I collection. Creating an electronic copy of this biographic information, or adding the information to TMS, could better inform researchers about the creators of the collection. Further cohesiveness can be achieved through fully cataloguing the photographs in Klinsky II. Presently there are less than 100 complete records in TMS for the entire Klinsky II collection. Completing a catalogue record for a small selection of the collection would benefit any researcher who was interested in the Klinsky collection in its entirety. 
The completion of the Klinsky I finding aid project proved challenging. Without physically reorganizing the photographs, the application of subject terms was very difficult. I found it hard to visualize what 300 photographs with the same term looked like without physically putting them together. Using 16 terms to describe over 9,000 photographs proved to be a very lengthy process. The completion of the Klinsky I finding aid provides 16 new access points to the collections contents and presents the completed project in three different ways. Reviewing and updating all of the records in TMS and Excel will provide new ways for users to view and search the collection's contents. The physical finding aid is easily accessed and displays to its users a different way of viewing the Klinsky I collection contents. The Klinsky I finding aid had one goal for the duration of the project, to promote new access points to the collection, which has been successfully achieved. 


\section{Bibliography}

Baca, Murtha, ed. Introduction to Metadata. Los Angeles, CA: Getty Research Institute (2008). Accessed March 14, 2015.

http://www.getty.edu/research/publications/electronic_publications/intrometadata/ index.html.

Bair, Nadya. "Never Alone: Photo Editing and Collaboration." In Getting the Picture: The Visual Culture of the News, edited by Jason E. Hill and Vanessa R. Schwartz, 228-35.

Benedetti, Joan M., ed. Art Museum Libraries and Librarianship. Lanham, MD: Scarecrow Press, 2007.

Bennett, K. S. "Basic Components of an Institutional Archive." In MRM5: Museum Registration Methods, edited by Rebecca A. Buck and Jean Allman Gilmore. 5th ed. Washington, DC: AAM Press, American Association of Museums, 2010.

Brennen, Bonnie, and Hanno Hardt. Picturing the Past: Media, History, and Photography. Urbana: University of Illinois Press, 1999.

Bunker, Lisa. "When Books Burn: Timeline of Nazi Germany." When Books Burn: An Online Exhibit (June 22, 2002). Accessed April 28, 2015. http://www.library.arizona.edu/exhibits/burnedbooks/timeline.htm.

Cataloging Historical Photographs in Olivia. Report. Cambridge, MA: Harvard University, 2008. Accessed April 25, 2015. http://preserve.harvard.edu/guidelines/cataloginghistoricalphotos.pdf.

"CDWA List of Categories and Definitions." In Categories for the Description of Works of Art, edited by Patricia Harpring. Los Angeles, CA: Getty Research Institute, 2014. Accessed June 14, 2015. http://www.getty.edu/research/publications/electronic_publications/cdwa/definitio ns.html. 
"Chronology of the Holocaust." United States Holocaust Memorial Museum (2007). Accessed March 28, 2015. http://www.ushmm.org/educators/teachingmaterials/materials-by-topic\#law.

Corrado, Edward M., and Heather Lea Moulaison. Digital Preservation for Libraries, Archives, and Museums. Rowman \& Littlefield (2014). doi:doi:http://ryerson.eblib.com/patron/FullRecord.aspx?p=1676304.

Eksteins, Modris. The Limits of Reason: The German Democratic Press and the Collapse of Weimar Democracy. London: Oxford University Press, 1975.

Eskildsen, Ute. "Willi Ruge and Fotoaktuell: Adventures for the Press." In Object:Photo. Modern Photographs: The Thomas Walther Collection 1909-1949. An online project of The Museum of Modern Art. New York: Museum of Modern Art (2014): 1-13. Accessed June 23, 2015. http://www.moma.org/interactives/objectphoto/assets/essays/Eskildsen.pdf.

Freund, Gisèle. Photography \& Society. Boston: D.R. Godine, 1980.

Fulda, Bernhard. Press and Politics in the Weimar Republic. Oxford: Oxford University Press, 2009.

Gidal, Tim. Modern Photojournalism: Origin and Evolution, 1910-1933. New York: Macmillan, 1973.

Gürsel, Zeynep Devrim. "A Short History of Wire Service Photography." In Getting the Picture: The Visual Culture of the News, by Jason E. Hill and Vanessa R. Schwartz, 206-11.

Hale, Oron J. The Captive Press in the Third Reich. Princeton, NJ: Princeton University Press, 1964.

Hardt, Hanno. "Constructing Photojournalism in Weimar Germany, 1928-33." Communication Review 1, no. 3 (1996): 373-402. Accessed September 25, 2014. http://skylined.org/hardt/text5.htm. 
Harpring, Patricia. "Categories for the Description of Works of Art (Getty Research Institute)." Getty Research Institute, March 2014. Accessed April 14, 2015. http://www.getty.edu/research/publications/electronic_publications/cdwa/introd uction.html.

Harpring, Patricia. Introduction to Controlled Vocabularies Terminology for Art, Architecture, and Other Cultural Works. Los Angeles, CA: Getty Research Institute, 2010. Accessed April 30, 2015.

http://www.getty.edu/research/publications/electronic_publications/intro_contro lled_vocab/context.html.

Hill, Jason E., and Vanessa R. Schwartz. Getting the Picture: The Visual Culture of the News. New York: Bloomsbury, 2015.

Hodges, Ann E., and Brenda S. McClurkin. Archives and Manuscripts Processing Manual. 6th ed. Arlington, TX: Special Collections Division, the University of Texas at Arlington Libraries, 2011. Accessed April 26, 2015. https://www.uta.edu/library/spco/files/processing-manual.pdf.

Hunter, Gregory S. Preserving Digital Information: A How-to-do-it Manual. New York: Neal-Schuman Publishers, 2000.

Jeffrey, Ian. German Photographs of the 1930s: Royal Festival Hall, 1995. London: South Bank Centre, 1995.

Lebeck, Robert, and Bodo von Dewitz. Kiosk: A History of Photojournalism. Göttingen: Steidl, 2002.

Madamba, Rebecca. "The Schostal Collection: A Finding Aid for The Schostal Agency Collection at the Art Gallery of Ontario." Master's thesis, Ryerson University, 2014. Accessed October 30, 2014. http://digital.library.ryerson.ca/islandora/search/rebecca\%20madamba?type=dis $\max$. 
Magilow, Daniel H. "Photo of the Kellogg-Briand Pact Meeting, Paris, 1931." In Getting the Picture: The Visual Culture of the News, by Jason E. Hill and Vanessa R. Schwartz, 52-54.

Magilow, Daniel H. The Photography of Crisis: The Photo Essays of Weimar Germany. University Park, PA: Pennsylvania State University Press, 2012.

Magilow, Daniel H. The Space Between the Pictures: Photography, Literature, and the Late-Weimar Photo-Essay. 2003.

Manco, Sara L. "Finding Wolff: Intellectually Arranging the Werner Wolff Fonds at the Ryerson Image Centre.” Master's thesis, Ryerson University, 2012. Accessed December 1, 2014. http:/digital.library.ryerson.ca/islandora/search/sara\%20manco?type=dismax.

Marien, Mary Warner. Photography: A Cultural History. Upper Saddle River, NJ: Pearson Prentice Hall, 2011.

Neubauer, Hendrik. Black Star: 60 Years of Photojournalism. Köln: Könemann, 1997.

Newhall, Beaumont. The History of Photography from 1839 to Present. 3rd ed. S.1.: Secker and Warburg, 1964.

O'Brien, Jeff. Basic RAD: An Introduction to the preparation offonds- and series-level descriptions using the Rules for Archival Description. Regina: Saskatchewan Council for Archives and Archivists, 1997. Accessed April 14, 2015. http://scaa.sk.ca/rad/radtoc.htm.

Palmér, Torsten, and Hendrik Neubauer. The Weimar Republic through the Lens of the Press. Cologne: Könemann, 2000.

Raphael, Scott E. "Censorship of the Media in Nazi Germany and Post-Revolutionary Iran: A Comparative Analysis as to Security in the Homeland." Master's thesis, California University of Pennsylvania, 2007. Accessed October 28, 2014. http://libweb.calu.edu/thesis/umi-cup-1065.pdf. 
Renwick, Brenda. Klinsky Archive: Notes on Photographers. AGO Internal Report, 2006.

Ritchin, Fred. "Close Witnesses: The Involvement of the Photojournalist." In A New History of Photography, edited by Michel Frizot. Köln: Könemann, 1998.

Rittelmann, Leesa L. "Constructed Identities: The German Photobook from Weimar to the Third Reich." PhD diss., University of Pittsburgh, 2002. Accessed April 25, 2015.

http://ezproxy.lib.ryerson.ca/login?url=http://search.proquest.com.ezproxy.lib.ry erson.ca/docview/305310912?accountid=13631.

Ritzenthaler, Mary Lynn, and Diane Vogt-O'Connor. Photographs: Archival Care and Management. Chicago: Society of American Archivists, 2006.

Rules for Archival Description (RAD2). Ottawa: Canadian Council of Archives, 2008. Accessed October 30, 2014. http://www.cdncouncilarchives.ca/RAD/RAD_Principles_July2008.pdf.

Smith, Cynthia Zoe. Emigré Photography in America: Contributions of German Photojournalism from Black Star Picture Agency to Life Magazine, 1933-1938. PhD diss., University of Iowa, 1983. Accessed May 20, 2015. http://ezproxy.lib.ryerson.ca/login?url=http://search.proquest.com.ezproxy.lib.ry erson.ca/docview/303268738?accountid=13631.

Sundt, Christine L. "The Image User and the Search for Images." In Introduction to Art Image Access: Issues, Tools, Standards, Strategies, edited by Murtha Baca. Los Angeles: Getty Research Institute, 2002.

http://www.getty.edu/research/publications/electronic_publications/intro_aia/su ndt.html.

Sutnik, Maia-Mari. Outstanding Significance and National Importance: Klinsky Agency Archive. Report. July, 2002.

Thompson, Tim, Matt Carruthers, and Natalie Bauer. Guidelines for Formulating Subject Headings for Archival Collections. Miami: University of Miami, 2013. 
Accessed April 10, 2015.

http://ufdcimages.uflib.ufl.edu/AA/00/01/61/49/00013/Guidelines_for_Formulat ing_Subject_Headings_for_Archival_Collections.pdf.

Witkovsky, Matthew S., and Peter Demetz. Foto: Modernity in Central Europe, 19181945. Washington, DC: National Gallery of Art in Association with Thames and Hudson, 2007.

Woodley, Mary S. "Crosswalks, Metadata Harvesting, Federated Searching, Metasearching: Using Metadata to Connect Users and Information." In Introduction To Metadata, edited by Murtha Baca. Los Angeles, CA: Getty Information Institute, 2008.

Zervigón, Andrés Mario. "Rotogravure and the Modern Aesthetic of News Reporting." In Getting the Picture: The Visual Culture of the News, by Jason E. Hill and Vanessa R. Schwartz, 197-205.

Zinkham, Helena. Subject Indexing for Pictures: An Overview. Report. Washington DC: Library of Congress, 2004. Accessed April 25, 2015. http://www.loc.gov/rr/print/tp/Subject\%20Indexing\%20for\%20Pictures.pdf.

Zweers, Louis. "De Zwerftocht van Klinsky's Foto-archief." Trouw (May 4, 1996). Accessed April 23, 2015. http://www.trouw.nl/tr/nl/5009/Archief/article/detail/2613328/1996/05/04/Dezwerftocht-van-Klinsky-s-foto-archief.dhtml. 


\section{Appendix I: Historical Timeline}

Chronology of events in Nazi Germany pertaining to media censorship. ${ }^{73}$

February 4, $1933 \quad$ Law for the Protection of the German People. This law restricts demonstrations, freedom of speech, freedom of press, and allows the state to confiscate literature considered dangerous.

February 28,1933 Law for the Protection of People and the State. This law eliminates the following rights: free speech, free press, the sanctity of the home, security of mail and telephone, freedom to assemble or form organizations, and the security of private property. It is this law that leads to political opponents being imprisoned and the establishment of concentration camps.

March 5, 1933

The Third Reich is brought to power through elections. The Nazi Party wins a majority in the Reichstag.

March 6, 1933

Emergency Decree for the Protection of the German People. This decree places restrictions on the opposition press and information services.

March 11, 1933

The Reich Ministry of Propaganda and People's Enlightenment is established through law. Joseph Goebbels is named Propaganda Minister.

March 23, 1933

The Enabling Act. Parliamentary practice is brought to an end through this act. Henceforth Hitler's regime can create laws without Reichstag sanction.

September 22, 1933

Reich Chamber of Culture is created to control all literature, press, radio, theater, music, and art. Goebbels directs these efforts. A policy of banning "non-Aryans" from contributing to these fields is enacted.

\footnotetext{
73 Raphael, Scott E. "Censorship of the Media in Nazi Germany and Post-Revolutionary Iran: A Comparative Analysis as to Security in the Homeland" (master's thesis, California University of Pennsylvania, 2007), 69.
} 
October 4, 1933

December 18, 1933

June 5, 1935

September 15, 1935
A law regulating the function of newspaper and periodical editors is enacted. Commonly referred to as "editorial law". ${ }^{74}$

Nazi decree prohibits Jews from the industries of journalism and its associated professions.

Decreed a violation to review books that are not aligned with the Nazi Party and government. Goebbels and the Chamber of Culture "coordinates" all the official literary criticism. ${ }^{75}$

Law for the Protection of German Blood and German Honor. This is one of the Nuremberg laws. With this law, all Jewish and Jewish-related authors, publishers, editors, etc., are excluded from the cultural life of Germany. ${ }^{76}$

\footnotetext{
74 Ibid.

${ }^{75}$ Lisa Bunker, "When Books Burn: Timeline of Nazi Germany," When Books Burn: An Online Exhibit (June 22, 2002), 1.

${ }^{76}$ For additional chronology, see "Chronology of the Holocaust," United States Holocaust Memorial Museum (2007).
} 


\section{Appendix II: Klinsky I Subject Index}

1. Politics (the following subjects are represented by this term)

-Politicians

-Political events

-Conferences

-Strikes/Riots/Rallies/Protests/Demonstrations/Parades

-Elections

2. Military (the following subjects are represented by this term)

-Generals

-Armies

-Soldiers

-Memorials

-Battle Scenes

\section{Aviation}

4. Maritime

5. Sciences (the following subjects are represented by this term)

-Astronomy

-Chemistry

-Physics

-Medical

-Natural Sciences (including Biology-Botany)

-Paleontology

-Engineering (including Transportation, Technology, Electronic engineering-

e.g., camera equipment)

6. Criminology (the following subjects are represented by this term)

-Law Enforcement,

-Court Proceedings (unless political)

-Criminals

-Crime Scenes

7. Disasters/Accidents (the following subjects are represented by this term) 
-Natural Disasters

-Planes/Trains/Automobile accidents

8. Daily Life (the following subjects are represented by this term)

-Fashion

-Urban Life

-Rural Life

-Labour - Agriculture, Industry

-Evacuations/Refugees/Casualties of Conflict

-Architecture

9. The Arts (the following subjects are represented by this term)

-Fine Art

-Music

-Dance

-Dramatic Arts (including Theatre and Film)

10. Celebrities

11. Sports (the following subjects are represented by this term)

-Activities

-Events (including the Olympics and Races)

12. Children

13. Women

14. Royalty

15. Religion

16. Celebrations (the following subjects are represented by this term)

-Festivals

-World Fairs

-Expositions 


\section{Appendix III: Klinsky Subject Terms/Getty Concepts Conversion Chart}

This chart demonstrates how the Klinsky I terms were converted to Getty AAT terms, which where then applied in TMS. Getty AAT terms are based on a hierarchical relationship, and each facet of the hierarchy was included to show users how each final term was found within the AAT hierarchy.

\begin{tabular}{|c|c|}
\hline Klinsky I Terms & Getty $A A T$ Terms \\
\hline Politics & $\begin{array}{l}\text { (Associate concepts facets), } \\
\text { (associated concepts hierarchy) } \\
\text {...Social sciences concepts, } \\
\text { (political concepts) }\end{array}$ \\
\hline Military & $\begin{array}{l}\text { Agent Facet, } \\
\text { Organization (hierarchy name) } \\
\text { organization (groups), } \\
\text {...armed forces }\end{array}$ \\
\hline Aviation & $\begin{array}{l}\text { Activities Facet, } \\
\text { Disciplines (hierarchy name) } \\
\text { disciplines }<\text { science and related } \\
\text { disciplines }> \\
\text { science, } \\
\text { aeronautics, } \\
\text {...aviation }\end{array}$ \\
\hline Maritime & $\begin{array}{l}\text { Agent Facet, } \\
\text { Organization (hierarchy name) } \\
\text { organization (groups), } \\
\text { armed forces, } \\
\text {...navies }\end{array}$ \\
\hline Sciences & $\begin{array}{l}\text { (Associate concepts facets), } \\
\text { (associated concepts hierarchy)... } \\
\text { Scientific concepts }\end{array}$ \\
\hline
\end{tabular}




\begin{tabular}{|c|c|}
\hline Criminology & $\begin{array}{l}\text { (Associate concepts facets), } \\
\text { (associated concepts hierarchy) } \\
\text {...Social sciences concepts, } \\
\text { (legal concepts) } \\
\text { <crime> }\end{array}$ \\
\hline Daily Life & $\begin{array}{l}\text { (Associate concepts facets), } \\
\text { (associated concepts hierarchy) } \\
<\text { culture and related concepts }>\end{array}$ \\
\hline The Arts & $\begin{array}{l}\text { (Associate concepts facets), } \\
\text { Art, } \\
\text { agents (general), } \\
<\text { concepts in the arts> }\end{array}$ \\
\hline Celebrities & $\begin{array}{l}\text { Agents Facet, } \\
\text { People (hierarchy name), } \\
\text { people (agents), } \\
<\text { people by state or condition> } \\
\text {...celebrities }\end{array}$ \\
\hline Celebrations & $\begin{array}{l}\text { Activities Facet, } \\
\text { Events (hierarchy name) } \\
\text { events (activities) } \\
\text {...celebrations }\end{array}$ \\
\hline Children & $\begin{array}{l}\text { Agents Facet, People (hierarchy name), } \\
\text { people (agents), } \\
\text { <people by age group> } \\
\text { children }\end{array}$ \\
\hline Women & $\begin{array}{l}\text { Agents Facet, People (hierarchy name), } \\
\text { people (agents), } \\
\text { <people by gender> } \\
\text { women }\end{array}$ \\
\hline
\end{tabular}




\begin{tabular}{|c|c|}
\hline Royalty & $\begin{array}{l}\text { Agents Facet, People (hierarchy name), } \\
\text { people (agents), } \\
\text { groups of people } \\
\text { Social groups, social classes, } \\
\text { <social classes by specific type> } \\
\text { upper class, } \\
\text { aristocracy (social class) } \\
\text { nobility, } \\
\text { royalty (nobility) }\end{array}$ \\
\hline Religion & $\begin{array}{l}\text { (Associate concepts facets), } \\
\text { (associated concepts hierarchy) } \\
\text {...(religion and religious concepts) } \\
<\text { religious concepts }>\end{array}$ \\
\hline Sports & $\begin{array}{l}\text { Activities Facet, } \\
\text { Events (hierarchy name) } \\
\text { events (activities) } \\
\text {...celebrations } \\
\text { Activities Facet, } \\
\text { Physical and Mental Activities (hierarchy } \\
\text { name) } \\
\text { physical activities, } \\
<\text { physical activities by specific context> } \\
<\text { public and interactive activities }>\text { games, } \\
\text { sports }\end{array}$ \\
\hline
\end{tabular}


Appendix IV: Selected Biographies

\section{Individual Photographers}

Eric Borchert (1900-1942), German

Worked in Berlin in the 1920s for Pacific \& Atlantic and in the 1930s for the Associated Press. During the 1930s he mainly photographed affairs on the home front, creating photo stories that related to German history and industry. Photographs show both nationalist and provincial topics. ${ }^{77}$ In 1938 he spent a brief time in the USA. In 1940 he covered the political scene in Poland and later created a photo essay on French war veterans and their responses to the regime in Germany. He was working as a war photographer with the German forces in North Africa when he was killed in 1942.

Robert Capa (Andre Friedman) (1913-1954), American

First story was published in the Berliner Illustrierte Zeitung in 1931. Became a Berlin correspondent for Dephot Agency and moved to Paris in 1933 to work for $V u$ magazine, then immigrated to the USA in 1939. He covered wars in Spain, China, Israel, and Indochina.

Fritz Eschen (1900-1964), German

Eschen worked for Presse-Photo during the 1930s and was considered a modernist and a member of the National Socialist movement. ${ }^{78}$ His photographs focus on modern subjects including aviators, the Olympic stadium, and airships. ${ }^{79}$

\section{Alfred Eisenstaedt (1898-1995), American}

Began working for German illustrated weekly magazines in 1927. Freelanced for Associated Press in 1928 and later formed a close relationship with Klinsky in

\footnotetext{
${ }^{77}$ Jeffrey, 13

${ }^{78}$ Jeffrey, 13

${ }^{79}$ Ibid.
} 
Amsterdam. ${ }^{80}$ Covered European cultural and political events from 1928 to 1935 before immigrating to the USA.

John Gutmann (1903-1998), American

A painter turned photographer, Gutmann began working as a photojournalist in 1933 for Presse-Photo. Immigrating to the USA in 1936, Gutmann signed with Pix Publishing, an agency he worked with for over twenty years. Gutmann was struck by the popular culture of America and explored ideas of America with his photography. ${ }^{81}$

\section{E.O. Hoppé (1878-1972), British}

Hoppé first worked as an art photographer and operated a portrait studio. During the 1920s he expanded his subject interest to cultural and social events, and photographed many themes relating to daily life in London. Hoppé's photo essays were published in illustrated weeklies throughout Europe.

\section{Ihee Kimura (1901-1974), Japanese}

A self-taught photographer, Kimura became a pioneer of twentieth-century Japanese photography. ${ }^{82}$ He operated a portrait studio in Tokyo in 1924 and also worked in advertising photography. Kimura's photographs were published both in illustrated magazines and newspapers, and in 1937 he became a photographer for Berliner Illustrierte Zeitung.

Felix H. Man (Hans Felix Sigismund Baumann) (1893-1985), British Man took up photography while serving in the army in 1915, was later hired by the Ullstein newspaper around 1926, and then joined the Dephot agency in 1928. By 1934 more than 100 of Man's photo essays had been published, primarily in the Münchner Illustrierte Presse. ${ }^{83}$ Man emigrated to England in 1934 and continued to work as a photojournalist for such publications as Weekly Illustrated and Picture Post.

\footnotetext{
${ }^{80}$ Brenda Renwick, Klinsky Archive: Notes on Photographers, AGO Internal Report (2006), 1.

${ }^{81}$ Ibid.

82 Renwick, 2.

${ }^{83}$ Renwick, 2.
} 
Martin Munkácsi (1896-1963), Hungarian

Munkácsi moved to Berlin and began working for Ullstein in $1927 .{ }^{84}$ His photographs were published in Berliner Illustrierte Zeitung and the Dame and in other European illustrated magazines. He immigrated to the USA in 1934 and later became the best-paid fashion photographer of the 1940 s. $^{85}$

\section{Willi Ruge (1892-1961), German}

Served in the Luftwaffe as a photo reporter from 1914 to 1918 . Owned and operated his own picture agency, Fotoaktuell, in Berlin. Ruge often created staged domestic photo narratives, featuring his friends, family, and himself. ${ }^{86} \mathrm{He}$ was recognized as a specialist in aviation photography. His prowess in photography was discussed in several articles published by German magazines in the 1930s.$^{87}$ Ruge's photographs are considered quite rare because his archive was destroyed during a raid in Berlin in $1943 .{ }^{88}$

\section{Ilse Steinhoff (1909-1974), German}

Independent modernist female photographer. One of the first photojournalists to work with a square format camera during the 1930s. ${ }^{89}$

Walter Süssmann (known as Lueder, and Walter Sanders), (1918-2001), Austrian A principal photographer in Berlin during the 1930s, he worked for multiple picture agencies including Presse-Foto, and Pacific \& Atlantic. He was known for his interest in travel photography and photographed Spain, Romania, Italy, Cuba, and the Mediterranean. ${ }^{90}$ He worked in Berlin until 1937 when he immigrated to the USA.

\footnotetext{
${ }^{84}$ Torsten Palmér and Hendrik Neubauer, The Weimar Republic through the Lens of the Press (Cologne: Könemann, 2000), 396.

${ }^{85}$ Ibid.

${ }^{86}$ Renwick, 3.

${ }^{87}$ Eskildsen, 10.

${ }^{88}$ Ibid, 11.

${ }^{89}$ Jeffrey, 13.

90 Ibid.
} 


\section{Dr. Paul Wolff (1887-1951), German}

He began working as a photographer in 1926. Wolff used a Leica $35 \mathrm{~mm}$ camera in all of his work. He started selling his photographs to picture agencies in 1928, he was known for his experimental photography techniques, including microphotography. ${ }^{91}$ He opened a portrait studio in Berlin in $1930 .^{92}$

\section{Umbo (Otto Umbehr) (1902-1980), German}

He worked as a photojournalist for the Dephot agency in 1928, and as a staff photographer for Ullstein publishing agency. ${ }^{93}$ He also worked as a freelance photographer for publications such as Der Spiegel, and Picture Post. ${ }^{94}$

\section{Picture Agencies}

\section{Associated Press of Berlin}

Formerly known as Pacific \& Atlantic, this picture agency was bought by Associated Press in 1930.

\section{Dephot (Deutscher Photodienst)}

Simon Guttmann acted as director of the agency from 1928 to 1933. One of the most important agencies which provided photographs and full text reports for publications. ${ }^{95}$

\section{Pacific \& Atlantic}

Specialized initially in Berlin life. It had two main photographers: Alfred Eisenstaedt and Eric Borchert. Later became the Associated Press.

\footnotetext{
${ }^{91}$ Renwick, 3.

${ }^{92}$ Ibid.

${ }^{93}$ Ibid.

${ }^{94}$ Ibid.

${ }^{95}$ Palmér and Neubauer, 386.
} 


\section{Neofot}

Set up in the mid 1930s. It was a documentary agency with an educational, liberal, and medical bias. ${ }^{96}$ Photographers also reported on life in Eastern Europe.

\section{Fotoaktuell}

Owned and operated by Willi Ruge.

\section{Presse-Photo}

Had a worldwide brief, with particular interest in the United States.

${ }^{96}$ Jeffrey, 13. 


\section{Illustrations}

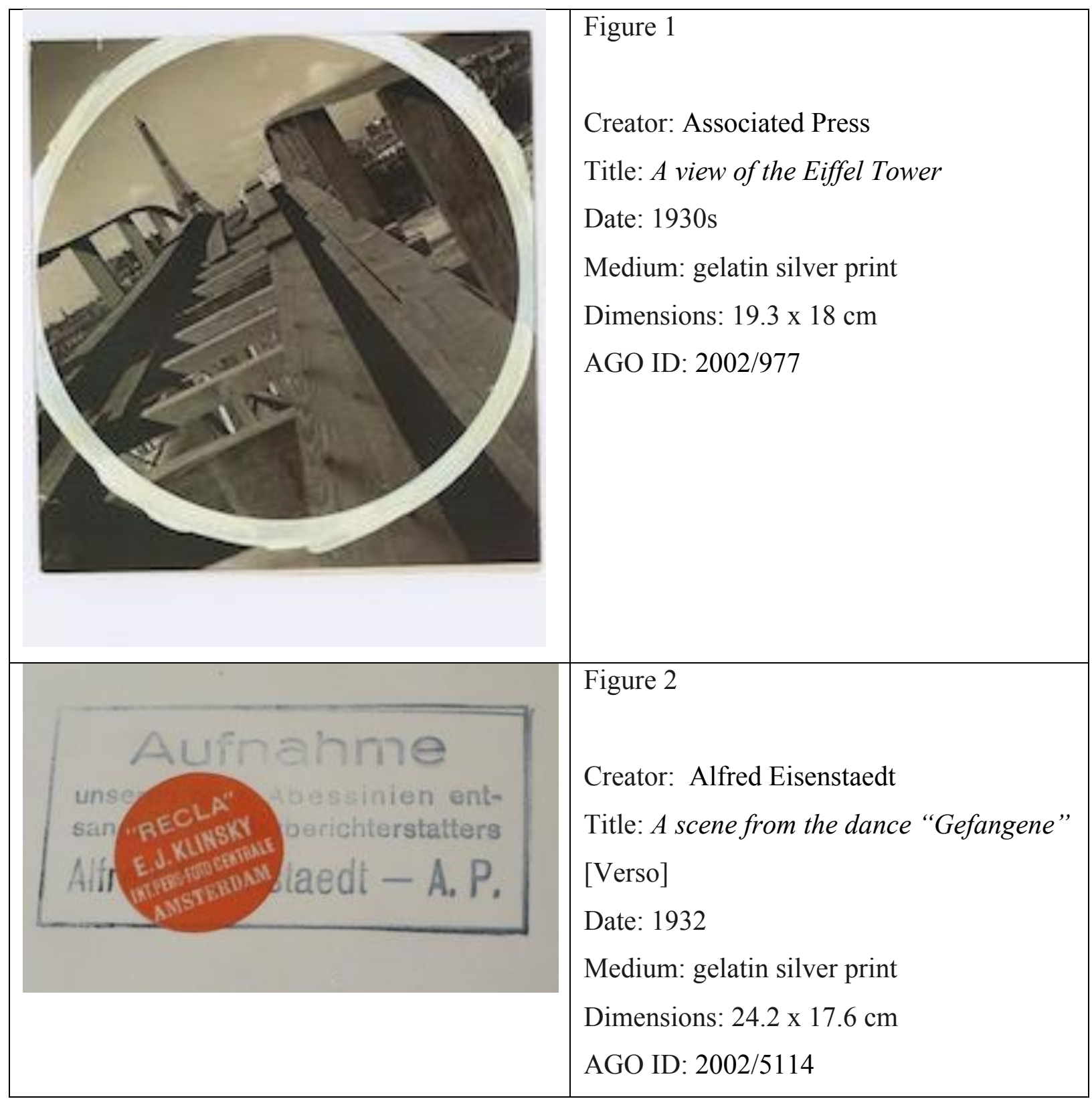




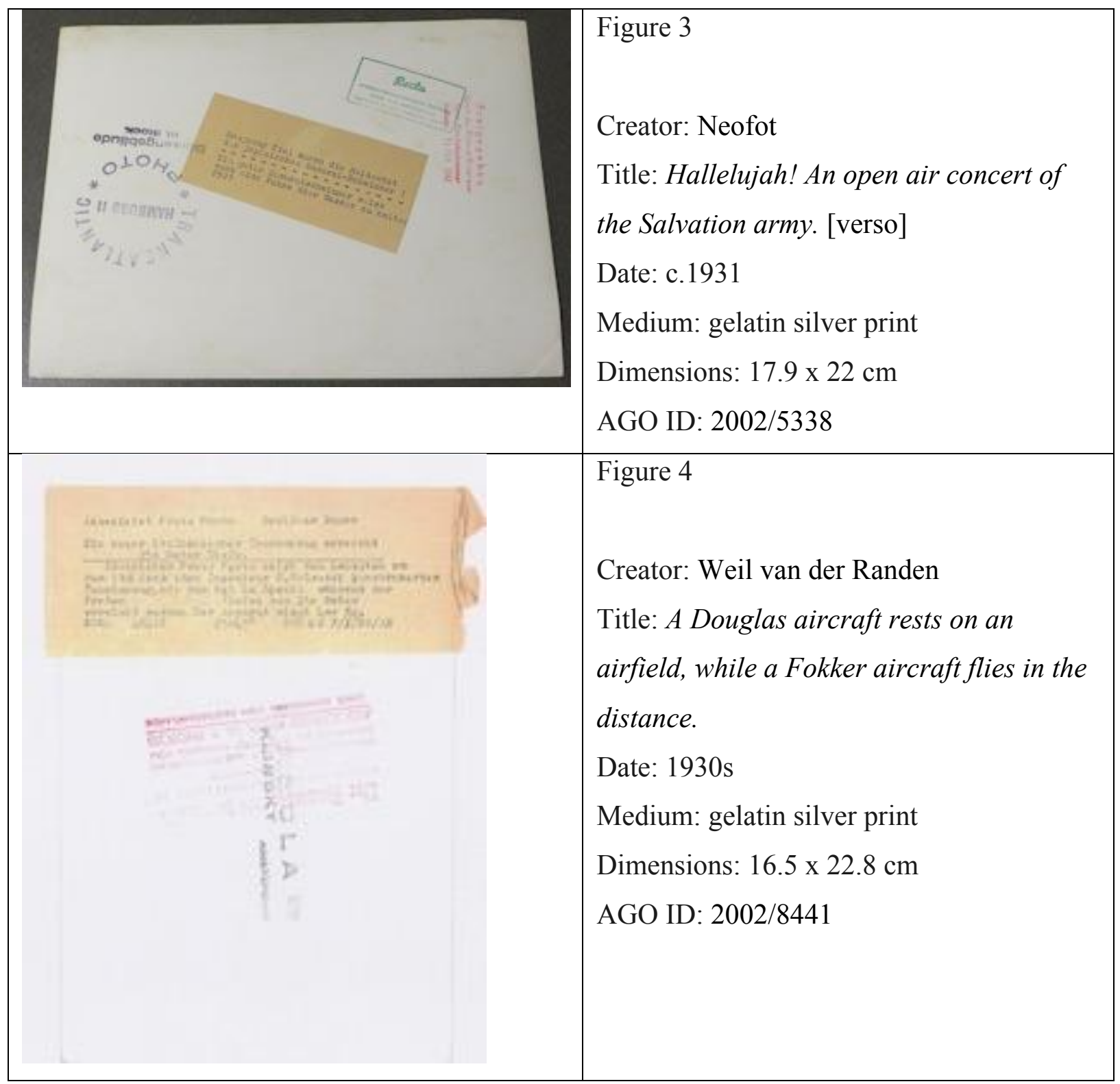




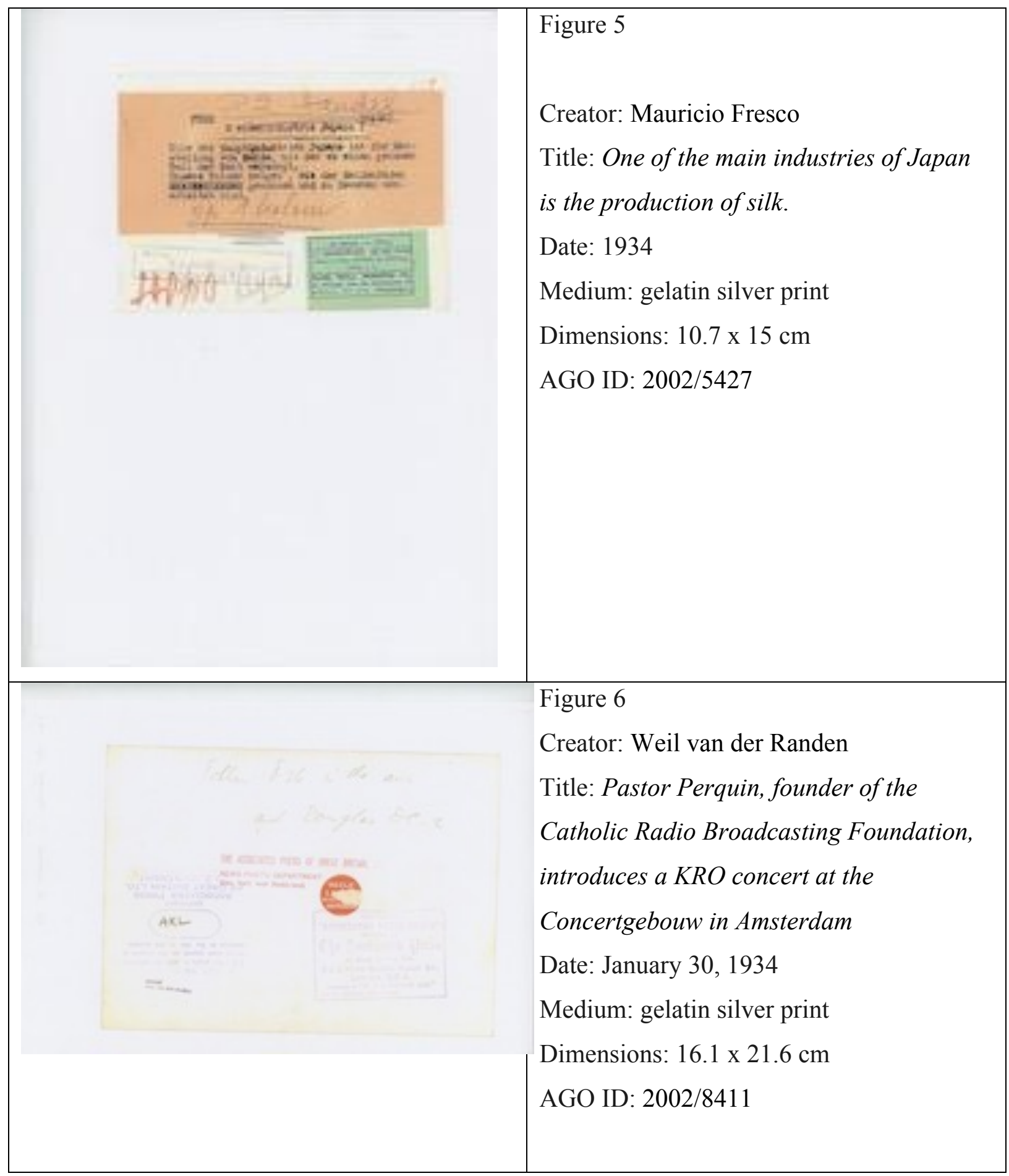




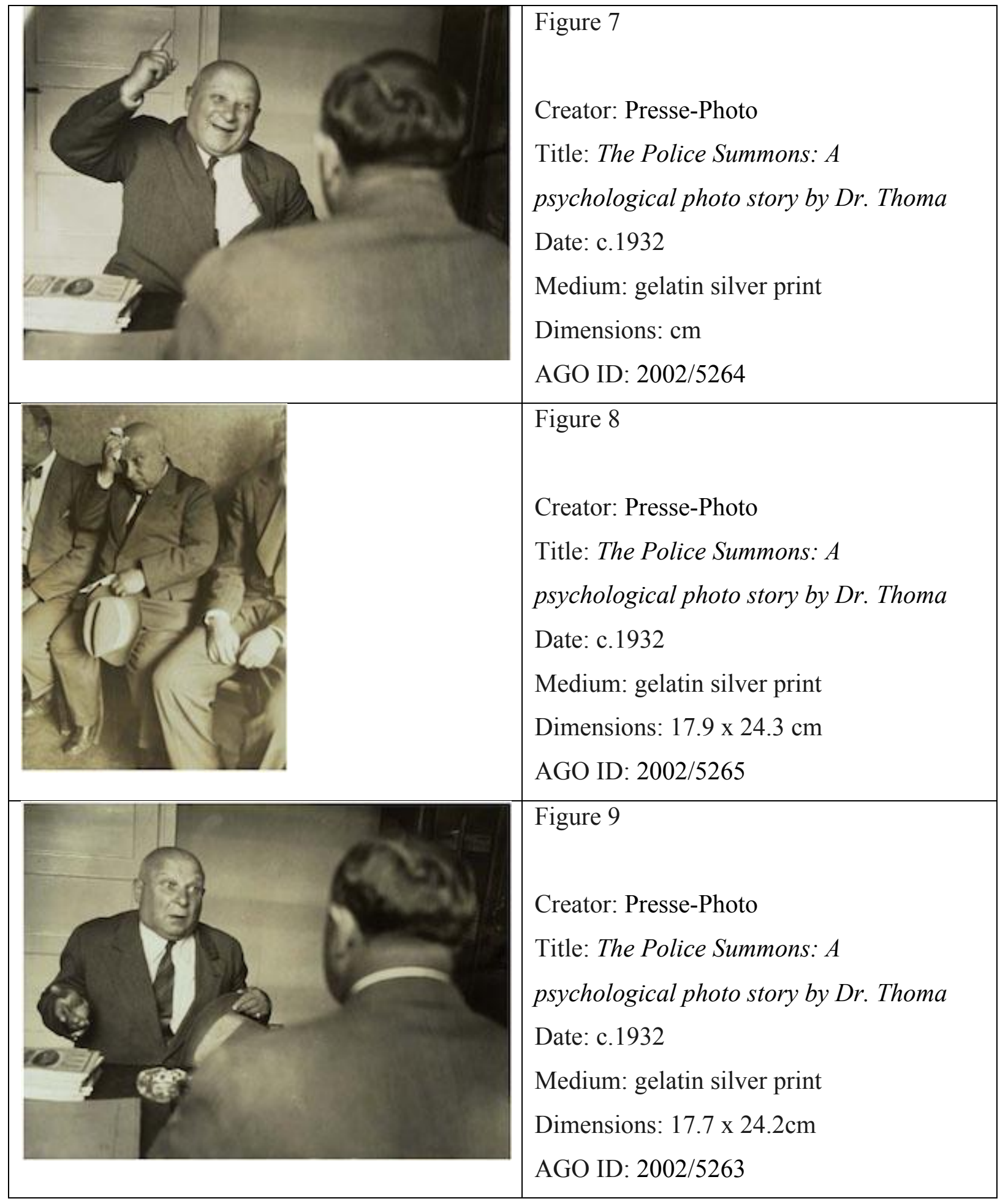



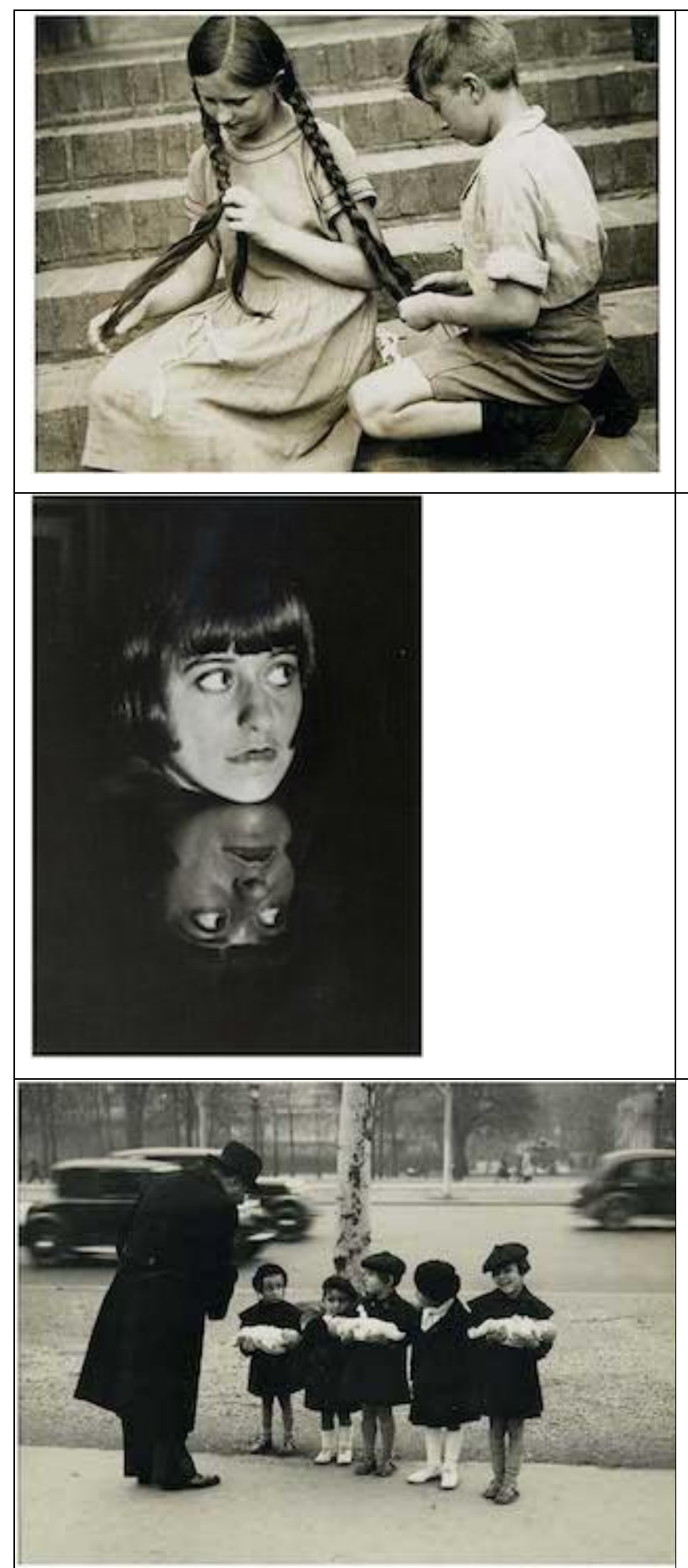

Figure 10

Creator: Alfred Eisenstaedt

Title: Camp "Youth and the Cross"

Date: 1932

Medium: gelatin silver print

Dimensions: 18.2 x $24.5 \mathrm{~cm}$

AGO ID: 2002/5282

Figure 11

Creator: Alfred Eisenstaedt

Title: Frau Margarete Turgel: Head and reflection of the woman who created and patented a playful zoo in silver foil

Date: 1931

Medium: gelatin silver print

Dimensions: 24.4 x $18 \mathrm{~cm}$

AGO ID: 2002/5287

Figure 12

Creator: Eric Borchert

Title: This picture shows what little success the French propaganda has had regarding the fall in the birth rate

Date: 1934

Medium: gelatin silver print

Dimensions: 18.1 x $24.3 \mathrm{~cm}$

AGO ID: 2002/5370 


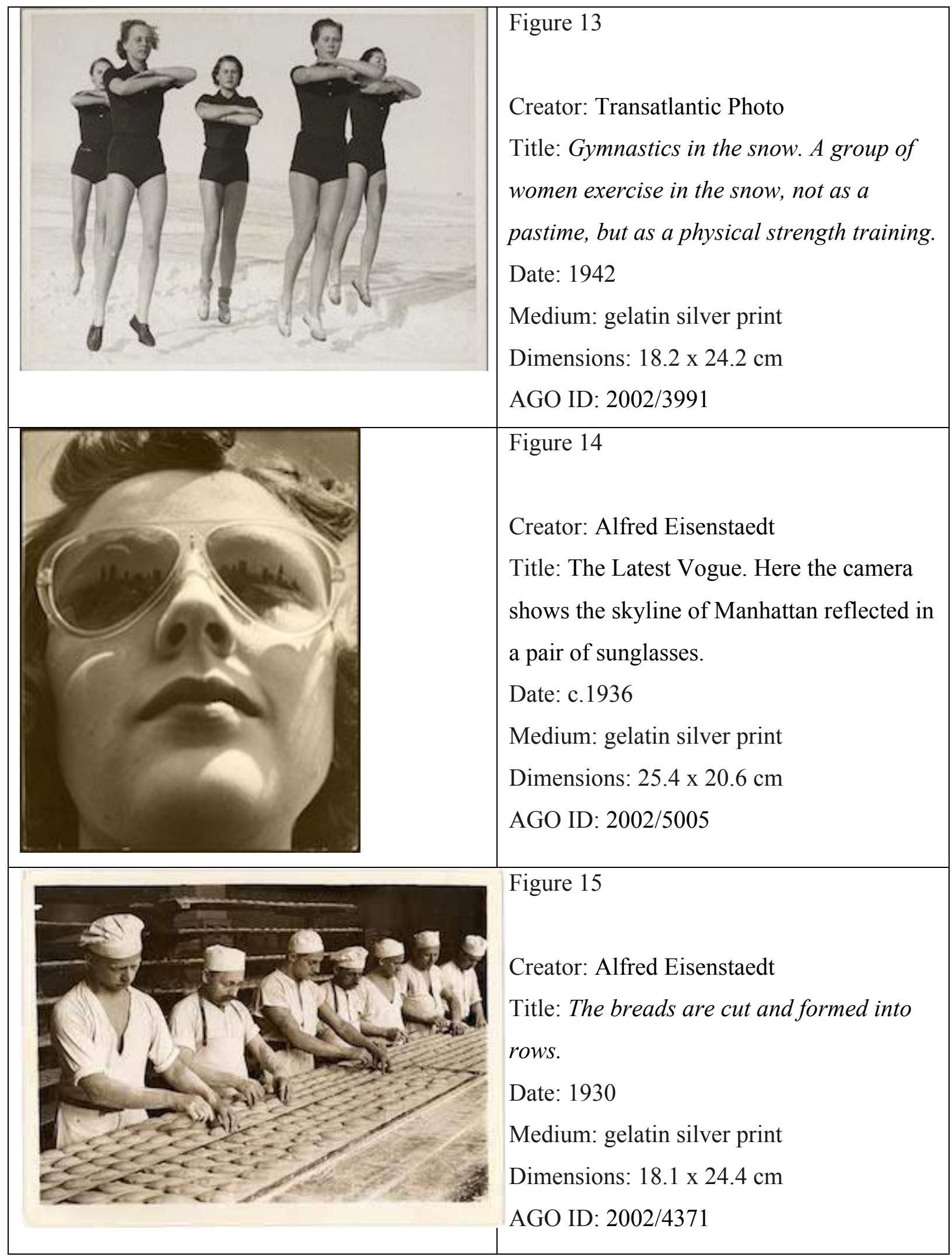


PART II: FINDING AID

The Klinsky Press Collection (1930-1945)

Finding aid prepared by Lisa Yarnell

Art Gallery of Ontario

\section{Contact Information:}

The Art Gallery of Ontario

317 Dundas Street West

Toronto, Ontario

Canada

M5T 1G4

Reference Desk Phone: 416-979-6660 x259

Date Completed: September 2015 


\section{A. Descriptive Summary}

Title:

Klinsky I Press Collection

Statement of Responsibility:

Emil J. Klinsky

Location:

AGO, PDC, CS4A, Bays 1-4

Inclusive Dates:

1929-1945

Extent:

9,236 photographs: b\&w; $18 \times 24 \mathrm{~cm}$ or smaller

\section{Description:}

The Klinsky I collection encompasses 9,236 German press photographs, assembled from illustrated magazines and press agencies from the 1930s. The collection contains photographs produced by the most well-known press photographers working in Germany during the 1930s. There are over 400 photographs made by Alfred Eisenstaedt in the collection as well as works made by recognized photographers such as Eric Borchert, Ilse Steinhoff, John Gutmann, Willi Ruge, and Walter Sussman. Photographic essays make up the bulk of the collection - the variety of subjects covered by picture stories capture the lifestyles, traditions, and culture of the German people during the interwar period and the beginning of WWII. The numerous photographic essays chronicle the rise and refinement of photo reportage during the 1930s.

\section{Language:}

Collection materials in German and English 


\section{Provenance:}

Anonymous gift to the AGO in 2002 


\section{B. Administrative Information}

\section{Access:}

Limited access to the collection is provided in the Marvin Gelber Print and Drawing Study Centre at the Art Gallery of Ontario.

\section{Walk-in Visits:}

Wednesdays $1 \mathrm{pm}$ to $8 \mathrm{pm}$

\section{By Appointment:}

Thursdays and Fridays

\section{Appointment Information:}

To make an appointment, please contact the Art Gallery of Ontario at least two weeks in advance.

Phone: 416-979-6600 extension: 535

\section{Publication Rights:}

Permission from the Art Gallery of Ontario is required for any and all publication of materials.

\section{Preferred Citation:}

The Klinsky I Collection, at the Art Gallery of Ontario. 


\section{Scope and Content}

The Klinsky I Collection is comprised of 9,236 gelatin silver prints; the photographs were created during the years of 1929 to 1945 . The collection was created from the archives of a picture distribution agency, Recla, which was located in Amsterdam and handled picture distribution for numerous Berlin-based picture agencies, as well as international agencies. The Klinsky Collection represents many picture agencies including Associated Press of Berlin, Keystone Press Agency, Pix Publishing Agency, and Presse-Photo Agency. There are seven major picture agencies that contributed to the collection, as well as numerous small picture agencies. Additionally, many individual photographers have large holdings in the collection-over 30 solander boxes are dedicated to individual photographers' works, including Eric Borchert, Robert Capa, Alfred Eisenstaedt, Ihee Kimura, Lotte Errell, Willi Ruge, and many more. There are 31 solander boxes labeled with the term "Agencies and Photographers". These boxes contain pictures from many small picture agencies and lesser-known photographers.

\section{Organization and Arrangement}

The Klinsky I Collection is organized by agency and/or creator, and its contents are housed in 119 solander boxes, with each box containing 60-100 photographs per box. The photographs within each box are arranged in ascending accession number order. Each photograph in the Klinsky I Collection has a TMS generated label that displays its accession number, title, creator, date, donor information, and a scannable barcode. Each of the 119 boxes contains two TMS generated box lists: a list containing the contents of the box based on its location, and an itemized list, organized by accession number, describing the contents of the box. ${ }^{97}$

\footnotetext{
${ }^{97}$ Refer to Appendix III for Box List Information.
} 


\section{E. History of the Klinsky Collection}

Little is known about the life of Emil J. Klinsky or his picture agency, Recla. Curator of Photography at the Art Gallery of Ontario, Maia Sutnik, authored a research report about the Klinsky Press Agency collection before its acquisition in 2002, and this report is one of two credible sources found that discusses Klinsky's life. In Sutnik's report, she states that the dates of the establishment of the Klinsky Agency and Klinsky's lifespan are unclear and that a considerable amount of research is still needed to establish the chronology and history of the agency and its operator.

It is estimated that Emil S. Klinsky was born around 1899 in Russia. One source wrote that Klinsky briefly worked at Associated Press in 1929, but this is unconfirmed by Sutnik's report. Around 1930, Klinsky opened his picture agency, Recla, in Amsterdam, Holland. Recla, also known as Klinsky Press Agency, operated until the early 1940s, and the agency handled picture distribution for many successful Berlin-based picture agencies, including Keystone Press Agency, Dephot, Associated Press Berlin, and PressePhoto. In addition, Recla represented several international agencies, such as Pix Publishing, and foreign photographers like John Gutmann and Ihee Kimura. The photographs represent both German and international interests, and the contents display a

unique mixture of news and narrative picture press photography. ${ }^{98}$

Recla closed sometime before 1945 and its photographs were stored and preserved for nearly fifty years before being acquired by the Archive of Modern Conflict. The collection was separated into Klinsky I and Klinsky II by the Archive of Modern Conflict. The Klinsky I collection is considered to contain the top-tier photographs from the collection, while Klinsky II contains commercial stock photography. The Klinsky I collection was donated to the AGO in 2002, and its counterpart, Klinsky II, was donated in 2005 .

${ }^{98}$ Sutnik, 4 . 


\section{F. Selected Biographies}

\section{Individual Photographers}

Eric Borchert (1900-1942), German

Worked in Berlin in the 1920s for Pacific \& Atlantic and in the 1930s for the Associated Press. During the 1930s he mainly photographed affairs on the home front, creating photo stories that related to German history and industry. Photographs show both nationalist and provincial topics. ${ }^{99}$ In 1938 he spent a brief time in the USA. In 1940 he covered the political scene in Poland and later created a photo essay on French war veterans and their responses to the regime in Germany. He was working as a war photographer with the German forces in North Africa when he was killed in 1942.

Robert Capa (Andre Friedman) (1913-1954), American

First story was published in the Berliner Illustrierte Zeitung in 1931. Became a Berlin correspondent for Dephot Agency and moved to Paris in 1933 to work for $V u$ magazine, then immigrated to the USA in 1939. He covered wars in Spain, China, Israel, and Indochina.

Fritz Eschen (1900-1964), German

Eschen worked for Presse-Photo during the 1930s and was considered a modernist and a member of the National Socialist movement. ${ }^{100}$ His photographs focus on modern subjects including aviators, the Olympic stadium, and airships. ${ }^{101}$

\section{Alfred Eisenstaedt (1898-1995), American}

Began working for German illustrated weekly magazines in 1927. Freelanced for Associated Press in 1928 and later formed a close relationship with Klinsky in Amsterdam. ${ }^{102}$ Covered European cultural and political events from 1928 to 1935 before immigrating to the USA.

\footnotetext{
99 Jeffrey, 13.

100 Jeffrey, 13

101 Ibid.

${ }^{102}$ Brenda Renwick, Klinsky Archive: Notes on Photographers, AGO Internal Report (2006), 1.
} 
John Gutmann (1903-1998), American

A painter turned photographer, Gutmann began working as a photojournalist in 1933 for Presse-Photo. Immigrating to the USA in 1936, Gutmann signed with Pix Publishing, an agency he worked with for over twenty years. Gutmann was struck by the popular culture of America and explored ideas of America with his photography. ${ }^{103}$

\section{E.O. Hoppé (1878-1972), British}

Hoppé first worked as an art photographer and operated a portrait studio. During the 1920s he expanded his subject interest to cultural and social events, and photographed many themes relating to daily life in London. Hoppé's photo essays were published in illustrated weeklies throughout Europe.

\section{Ihee Kimura (1901-1974), Japanese}

A self-taught photographer, Kimura became a pioneer of twentieth-century Japanese photography. ${ }^{104} \mathrm{He}$ operated a portrait studio in Tokyo in 1924 and also worked in advertising photography. Kimura's photographs were published both in illustrated magazines and newspapers, and in 1937 he became a photographer for Berliner Illustrierte Zeitung.

Felix H. Man (Hans Felix Sigismund Baumann) (1893-1985), British Man took up photography while serving in the army in 1915, was later hired by the Ullstein newspaper around 1926, and then joined the Dephot agency in 1928. By 1934 more than 100 of Man's photo essays had been published, primarily in the Münchner Illustrierte Presse. ${ }^{105}$ Man emigrated to England in 1934 and continued to work as a photojournalist for such publications as Weekly Illustrated and Picture Post.

\footnotetext{
${ }^{103}$ Ibid.

${ }^{104}$ Renwick, 2.

${ }^{105}$ Renwick, 2.
} 
Martin Munkácsi (1896-1963), Hungarian

Munkácsi moved to Berlin and began working for Ullstein in $1927 .{ }^{106}$ His photographs were published in Berliner Illustrierte Zeitung and the Dame and in other European illustrated magazines. He immigrated to the USA in 1934 and later became the best-paid fashion photographer of the 1940s. ${ }^{107}$

\section{Willi Ruge (1892-1961), German}

Served in the Luftwaffe as a photo reporter from 1914 to 1918. Owned and operated his own picture agency, Fotoaktuell, in Berlin. Ruge often created staged domestic photo narratives, featuring his friends, family, and himself. ${ }^{108} \mathrm{He}$ was recognized as a specialist in aviation photography. His prowess in photography was discussed in several articles published by German magazines in the 1930s. ${ }^{109}$ Ruge's photographs are considered quite rare because his archive was destroyed during a raid in Berlin in 1943. ${ }^{110}$

\section{Ilse Steinhoff (1909-1974), German}

Independent modernist female photographer. One of the first photojournalists to work with a square format camera during the 1930 s. ${ }^{11}$

Walter Süssmann (known as Lueder, and Walter Sanders), (1918-2001), Austrian A principal photographer in Berlin during the 1930s, he worked for multiple picture agencies including Presse-Foto, and Pacific \& Atlantic. He was known for his interest in travel photography and photographed Spain, Romania, Italy, Cuba, and the Mediterranean. ${ }^{112} \mathrm{He}$ worked in Berlin until 1937 when he immigrated to the USA.

\footnotetext{
${ }^{106}$ Torsten Palmér and Hendrik Neubauer, The Weimar Republic through the Lens of the Press (Cologne: Könemann, 2000), 396.

${ }^{107}$ Ibid.

${ }^{108}$ Renwick, 3 .

${ }^{109}$ Eskildsen, 10.

${ }^{110}$ Ibid, 11.

111 Jeffrey, 13.

${ }^{112}$ Ibid.
} 


\section{Dr. Paul Wolff (1887-1951), German}

He began working as a photographer in 1926. Wolff used a Leica $35 \mathrm{~mm}$ camera in all of his work. He started selling his photographs to picture agencies in 1928, he was known for his experimental photography techniques, including microphotography. ${ }^{113}$ He opened a portrait studio in Berlin in 1930. ${ }^{114}$

\section{Umbo (Otto Umbehr) (1902-1980), German}

He worked as a photojournalist for the Dephot agency in 1928, and as a staff photographer for Ullstein publishing agency. ${ }^{115}$ He also worked as a freelance photographer for publications such as Der Spiegel, and Picture Post. ${ }^{116}$

\section{Picture Agencies}

\section{Associated Press of Berlin}

Formerly known as Pacific \& Atlantic, this picture agency was bought by Associated Press in 1930.

\section{Dephot (Deutscher Photodienst)}

Simon Guttmann acted as director of the agency from 1928 to 1933. One of the most important agencies which provided photographs and full text reports for publications. ${ }^{117}$

\section{Pacific \& Atlantic}

Specialized initially in Berlin life. It had two main photographers: Alfred Eisenstaedt and Eric Borchert. Later became the Associated Press.

\section{Neofot}

Set up in the mid 1930s. It was a documentary agency with an educational, liberal, and medical bias. ${ }^{118}$ Photographers also reported on life in Eastern Europe.

\footnotetext{
113 Renwick, 3.

114 Ibid.

115 Ibid.

${ }^{116}$ Ibid.

117 Palmér and Neubauer, 386.
} 


\section{Fotoaktuell}

Owned and operated by Willi Ruge.

\section{Presse-Photo}

Had a worldwide brief, with particular interest in the United States.

118 Jeffrey, 13. 


\section{G. Klinsky I Subject Index Terms}

1. Politics (the following subjects are represented by this term)

-Politicians

-Political events

-Conferences

-Strikes/Riots/Rallies/Protests/Demonstrations/Parades

-Elections

2. Military (the following subjects are represented by this term)

-Generals

-Armies

-Soldiers

-Memorials

-Battle Scenes

3. Aviation

4. Maritime

5. Sciences (the following subjects are represented by this term)

-Astronomy

-Chemistry

-Physics

-Medical

-Natural Sciences (including Biology-Botany)

-Paleontology

-Engineering (including Transportation, Technology, Electronic engineering-

e.g., camera equipment)

6. Criminology (the following subjects are represented by this term)

-Law Enforcement,

-Court Proceedings (unless political)

-Criminals

-Crime Scenes 
7. Disasters/Accidents (the following subjects are represented by this term)

-Natural Disasters

-Planes/Trains/Automobile accidents

8. Daily Life (the following subjects are represented by this term)

-Fashion

-Urban Life

-Rural Life

-Labour - Agriculture, Industry

-Evacuations/Refugees/Casualties of Conflict

-Architecture

9. The Arts (the following subjects are represented by this term)

-Fine Art

-Music

-Dance

-Dramatic Arts (including Theatre and Film)

10. Celebrities

11. Sports (the following subjects are represented by this term)

-Activities

-Events (including the Olympics and Races)

12. Children

13. Women

14. Royalty

15. Religion

16. Celebrations (the following subjects are represented by this term)

-Festivals

-World Fairs

-Expositions 


\section{H. Related Materials}

The counterpart of Klinsky I, the Klinsky II collection is certainly relevant to any researcher interested in the entirety of the collection. The Klinsky II collection contains well over 11,000 photographs. Although its contents are considered stock photography, the subjects display the interests of society during the 1930s. A binder containing the Klinsky II finding aid accompanies the collection, and can be located in the Prints and Drawing Vault at the AGO.

Additionally, the Klinsky I collection includes the following materials: four binders containing reference information relating to specific photographs and subject matter. Each binder contains an index at the front detailing the contents of the binders and the pictures mentioned. A binder containing biographical information on twenty photographers is an additional resource that users can consult for information. ${ }^{119}$ Five binders containing inkjet reproductions of selected photographs for the Klinsky I collection are another resource that should be considered.

\section{Notes to Researchers}

Consult Appendix I for instructions on how to use Excel database.

\footnotetext{
${ }^{119}$ See Appendix III for list of photographers' bios.
} 


\section{J. Bibliography}

Baca, Murtha, ed. Introduction to Metadata. Los Angeles, CA: Getty Research Institute, 2008. Accessed March 14, 2015.

http://www.getty.edu/research/publications/electronic_publications/intrometadata/ index.html.

Bair, Nadya. "Never Alone: Photo Editing and Collaboration." In Getting the Picture:

The Visual Culture of the News, by Jason E. Hill and Vanessa R. Schwartz, 22835.

Benedetti, Joan M., ed. Art Museum Libraries and Librarianship. Lanham, MD: Scarecrow Press, 2007.

Bennett, K. S. "Basic Components of an Institutional Archive." In MRM5: Museum Registration Methods, edited by Rebecca A. Buck and Jean Allman Gilmore. 5th ed. Washington, DC: AAM Press, American Association of Museums, 2010.

Brennen, Bonnie, and Hanno Hardt. Picturing the Past: Media, History, and Photography. Urbana: University of Illinois Press, 1999.

Bunker, Lisa. "When Books Burn: Timeline of Nazi Germany." When Books Burn: An Online Exhibit. June 22, 2002. Accessed April 28, 2015. http://www.library.arizona.edu/exhibits/burnedbooks/timeline.htm.

Cataloging Historical Photographs in Olivia. Report. Cambridge, MA: Harvard University, 2008. Accessed April 25, 2015. http://preserve.harvard.edu/guidelines/cataloginghistoricalphotos.pdf.

"CDWA List of Categories and Definitions." In Categories for the Description of Works of Art, edited by Patricia Harpring. Los Angeles, CA: Getty Research Institute, 2014. Accessed June 14, 2015. http://www.getty.edu/research/publications/electronic_publications/cdwa/definitio ns.html. 
"Chronology of the Holocaust." United States Holocaust Memorial Museum. 2007.

Accessed March 28, 2015. http://www.ushmm.org/educators/teachingmaterials/materials-by-topic\#law.

Corrado, Edward M., and Heather Lea. Moulaison. Digital Preservation for Libraries, Archives, and Museums. Rowman \& Littlefield, 2014.

doi:doi:http://ryerson.eblib.com/patron/FullRecord.aspx?p=1676304.

Eskildsen, Ute. "Willi Ruge and Fotoaktuell: Adventures for the Press." In Object:Photo. Modern Photographs: The Thomas Walther Collection 1909-1949. An Online Project of The Museum of Modern Art, 1-13. New York: Museum of Modern Art, 2014. Accessed June 23, 2015. http://www.moma.org/interactives/objectphoto/assets/essays/Eskildsen.pdf.

Freund, Gisèle. Photography \& Society. Boston: D.R. Godine, 1980.

Gidal, Tim. Modern Photojournalism: Origin and Evolution, 1910-1933. New York: Macmillan, 1973.

Hardt, Hanno. "Constructing Photojournalism in Weimar Germany, 1928-33." Communication Review 1, no. 3 (1996): 373-402. Accessed September 25, 2014. http://skylined.org/hardt/text5.htm.

Harpring, Patricia. "Categories for the Description of Works of Art (Getty Research Institute)." Getty Research Institute. March 2014. Accessed April 14, 2015. http://www.getty.edu/research/publications/electronic_publications/cdwa/introd uction.html.

Harpring, Patricia. Introduction to Controlled Vocabularies Terminology for Art, Architecture, and Other Cultural Works. Los Angeles, CA: Getty Research Institute, 2010. Accessed April 30, 2015. http://www.getty.edu/research/publications/electronic_publications/intro_contro lled_vocab/context.html. 
Hill, Jason E., and Vanessa R. Schwartz. Getting the Picture: The Visual Culture of the News. New York: Bloomsbury, 2015

Hodges, Ann E., and Brenda S. McClurkin. Archives and Manuscripts Processing Manual. 6th ed. Arlington, TX: Special Collections Division, the University of Texas at Arlington Libraries, 2011. Accessed April 26, 2015. https://www.uta.edu/library/spco/files/processing-manual.pdf.

Jeffrey, Ian. German Photographs of the 1930s: Royal Festival Hall, 1995. London: South Bank Centre, 1995.

Lebeck, Robert, and Bodo von. Dewitz. Kiosk: A History of Photojournalism. Göttingen: Steidl, 2002.

Madamba, Rebecca. "The Schostal Agency: A Finding Aid for the Schostal Press Collection at the Art Gallery of Ontario." Master's thesis, Ryerson University, 2014. September 2014. Accessed October 30, 2014. http://digital.library.ryerson.ca/islandora/search/rebecca\%20madamba?type=dis $\max$.

Magilow, Daniel H. "Photo of the Kellogg-Briand Pact Meeting, Paris, 1931." In Getting the Picture: The Visual Culture of the News, by Jason E. Hill and Vanessa R. Schwartz, 52-54.

Magilow, Daniel H. The Photography of Crisis: The Photo Essays of Weimar Germany. University Park, PA: Pennsylvania State University Press, 2012.

Magilow, Daniel H. The Space Between the Pictures: Photography, Literature, and the Late-Weimar Photo-Essay. 2003.

Manco, Sara. Finding Wolff: Intellectually Arranging the Werner Wolff Fonds at the Ryerson Image Centre. Master's thesis, Ryerson University, 2012. Accessed December 1, 2014. http://digital.library.ryerson.ca/islandora/search/sara\%20manco?type=dismax. 
Marien, Mary Warner. Photography: A Cultural History. Upper Saddle River, NJ: Pearson Prentice Hall, 2011.

Neubauer, Hendrik. Black Star: 60 Years of Photojournalism. Köln: Könemann, 1997.

Newhall, Beaumont. The History of Photography from 1839 to Present. 3rd ed. S.1.: Secker and Warburg, 1964.

O'Brien, Jeff. Basic RAD:An Introduction to the Preparation of Fonds- and Series-level Descriptions Using the Rules for Archival Description. Saskatchewan Council for Archives and Archivists, 1997. Accessed April 14, 2015. http://scaa.sk.ca/rad/radtoc.htm.

Palmér, Torsten, and Hendrik Neubauer. The Weimar Republic through the Lens of the Press. Cologne: Könemann, 2000.

Raphael, Scott E. "Censorship of the Media in Nazi Germany and Post-Revolutionary Iran: A Comparative Analysis as to Security in the Homeland." Master's thesis, California University of Pennsylvania, 2007. Accessed October 28, 2014. http://libweb.calu.edu/thesis/umi-cup-1065.pdf.

Rittelmann, Leesa L. Constructed Identities: The German Photobook from Weimar to the Third Reich. PhD diss., University of Pittsburgh, 2002. Accessed April 25, 2015.

http://ezproxy.lib.ryerson.ca/login?url=http://search.proquest.com.ezproxy.lib.ry erson.ca/docview/305310912? accountid=13631.

Ritzenthaler, Mary Lynn, and Diane Vogt-O'Connor. Photographs: Archival Care and Management. Chicago: Society of American Archivists, 2006.

Renwick, Brenda. Klinsky Archive: Notes on Photographers. AGO Internal Report. 2006.

Rules for Archival Description (RAD2). Ottawa: Canadian Council of Archives, 2008. July 2008. Accessed October 30, 2014. http://www.cdncouncilarchives.ca/RAD/RAD_Principles_July2008.pdf. 
Smith, Cynthia Zoe. Emigré Photography in America : Contributions of German Photojournalism from Black Star Picture Agency to Life Magazine, 1933-1938. PhD diss., University of Iowa, 1983. University of Iowa. Accessed May 20, 2015.

http://ezproxy.lib.ryerson.ca/login?url=http://search.proquest.com.ezproxy.lib.ry erson.ca/docview/303268738? accountid=13631.

Sundt, Christine L. "The Image User and the Search for Images." In Introduction to Art Image Access: Issues, Tools, Standards, Strategies, edited by Murtha Baca. Los Angeles: Getty Research Institute, 2002.

http://www.getty.edu/research/publications/electronic_publications/intro_aia/su ndt.html.

Sutnik, Maia-Mari. Outstanding Significance and National Importance: Klinsky Agency Archive. Report. 7.2002.

Thompson, Tim, Matt Carruthers, and Natalie Bauer. Guidelines For Formulating Subject Headings For Archival Collections. Miami: University of Miami, 2013. Accessed April 10, 2015. http://ufdcimages.uflib.ufl.edu/AA/00/01/61/49/00013/Guidelines_for_Formulat ing_Subject_Headings_for_Archival_Collections.pdf.

Witkovsky, Matthew S., and Peter Demetz. Foto: Modernity in Central Europe, 19181945. Washington, DC: National Gallery of Art in Association with Thames and Hudson, 2007.

Woodley, Mary S. "Crosswalks, Metadata Harvesting, Federated Searching, Metasearching: Using Metadata to Connect Users and Information." In Introduction To Metadata, edited by Murtha Baca. Los Angeles, CA: Getty Information Institute, 2008.

Zinkham, Helena. Subject Indexing for Pictures: An Overview. Report. Washington DC: Library of Congress, 2004. Accessed April 25, 2015. http://www.loc.gov/rr/print/tp/Subject\%20Indexing\%20for\%20Pictures.pdf. 
Zweers, Louis. "De Zwerftocht Van Klinsky's Foto-archief." Trouw, May 04, 1996.

Accessed April 23, 2015.

http://www.trouw.nl/tr/nl/5009/Archief/article/detail/2613328/1996/05/04/Dezwerftocht-van-Klinsky-s-foto-archief.dhtml. 


\section{K. Appendices}

Appendix I: Description and Instructions for Use of the Klinsky I Excel Workbook

The Klinsky I Excel Workbook contains all digital records belonging to the Klinsky Press Agency collection located in the Prints and Drawing Vault at the Art Gallery of Ontario.

The Excel workbook has been organized to mimic the physical arrangement of the collection. The Klinsky I photographs are organized by agency and/or creator, and the collection is housed in 119 solander boxes. Within each box, the photographs are organized in ascending order of their accession numbers. The digital records contained within this Excel workbook reflect this arrangement. Column C - Object Number displays each record's AGO accession number. Accession numbers are the primary way to search for an individual record within the TMS database. Column E - Title displays each record's alternate title - the records primary titles are in German, so their alternate English titles are used as primaries. Column F - Date corresponds to the date inscribed on the photograph or, if no date could be identified, the term 1930s was applied to the record. A small amount of photographs in the Klinsky I collection are stamped with a specific date, but with less than 1,000 photographs identified with an exact date, searching by chronology would be futile to any user looking to gain a broad understanding of the collection's contents. Column J - Current Location describes where each photograph can be physically located in the Prints and Drawing Vault-all locations are correct and have been verified. Column L - Artist Info contains the creators name or agency's information.

There are several ways to conduct a search within this workbook. The user can choose to search by Locations in Germany, Countries, Specific Location Outside of Germany, or Subject Terms.

Records that contain location information refer to a location that was stated in the photograph's title, caption, or description. The location does not describe the photographer's origin or where the photograph was printed or created, it only identifies the location that was printed or written on the photograph. Locations were not added 
based on visual identification, only based on textual information contained on the verso of the photograph. In some cases cities and countries were listed, but for the majority of photographs if a location was identified, only the country was listed. Column $\mathrm{N}$ Locations in Germany is limited to locations in Germany. If Germany was written on the back of a photograph without a specific location, the term Germany was applied to the record in Column $\mathrm{N}$.

Column O - Country Location displays all countries, excluding Germany, that were identified by the Klinsky I contents. When a photograph contained both a country and a specific location, the country was added to Column $\mathrm{O}$ of the record, and the specific location was recorded in Column P. The separation of country and specific place was done so that a country location search would yield all records that contain a country location, and records with a specific location wouldn't be discounted in the search. Column P - Specific Locations contains all locations that were specifically identified by the captions, titles, and/or descriptions of photographs.

Each record contains at least one subject term, so if the user wishes to conduct a subject terms search, their search will yield results. Secondary subject terms (and sometimes third subjects) were also identified and, in such cases, additional terms were applied to the record. It is possible to narrow the results of a subject search by searching within the

results for records with secondary terms. All terms used for the three subject columns are identical.

\title{
Column Description and Search Terms List for Excel Workbook
}

\author{
Column N - Locations in Germany \\ Stuttgart, Bavaria, Berlin, Munich, Leipzig, Hamburg, Dresden, Cologne, \\ Frankfurt, Düsseldorf
}

Column O - Country Location List 
U.S.A., England, France, Japan, Spain, China, Italy, Australia, Canada, Egypt, Thailand, Switzerland, Finland, Ukraine, Portugal, Turkey, Poland, Bulgaria, Austria, Czechoslovakia, Hungary, The Netherlands, Russia, Belgium, Africa

Columns Q - Subject

Politics, Military, Aviation, Naval, Sciences, Disasters, Criminology, Everyday

Life, The Arts, Celebrity, Sports, Children, Women, Royalty, Religion, Celebrations

Column R - Secondary Subject

Politics, Military, Aviation, Naval, Sciences, Disasters, Criminology, Everyday

Life, The Arts, Celebrity, Sports, Children, Women, Royalty, Religion, Celebrations

\section{Excel Subject Terms List for Columns Q-S}

Politics

Military

Aviation

Maritime

Sciences

Criminology

Disasters/Accidents

Daily Life

The Arts

Celebrities

Sports

Children

Women

Royalty

Religion

Celebrations 
Appendix II: Klinsky I Subject Terms Label Examples

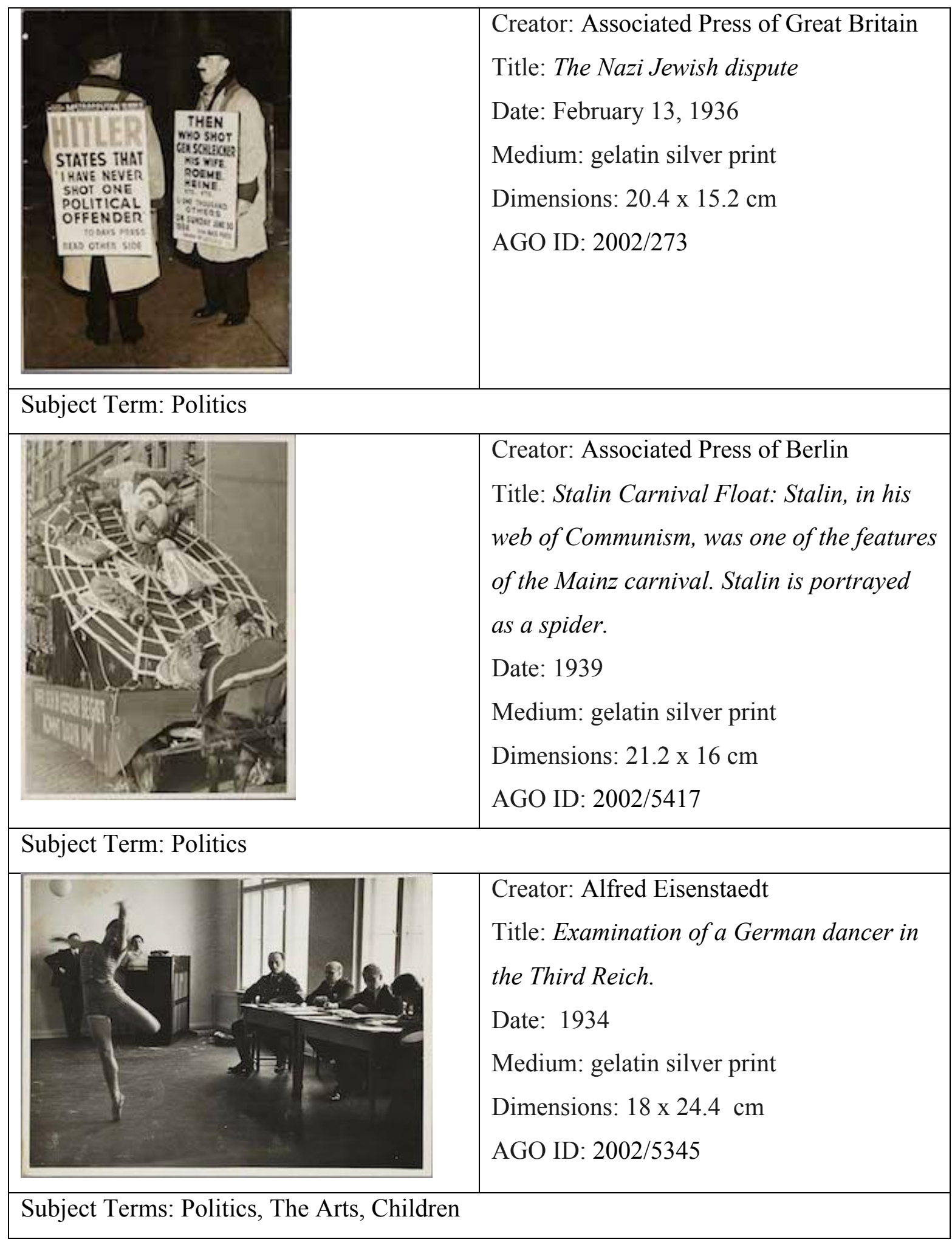




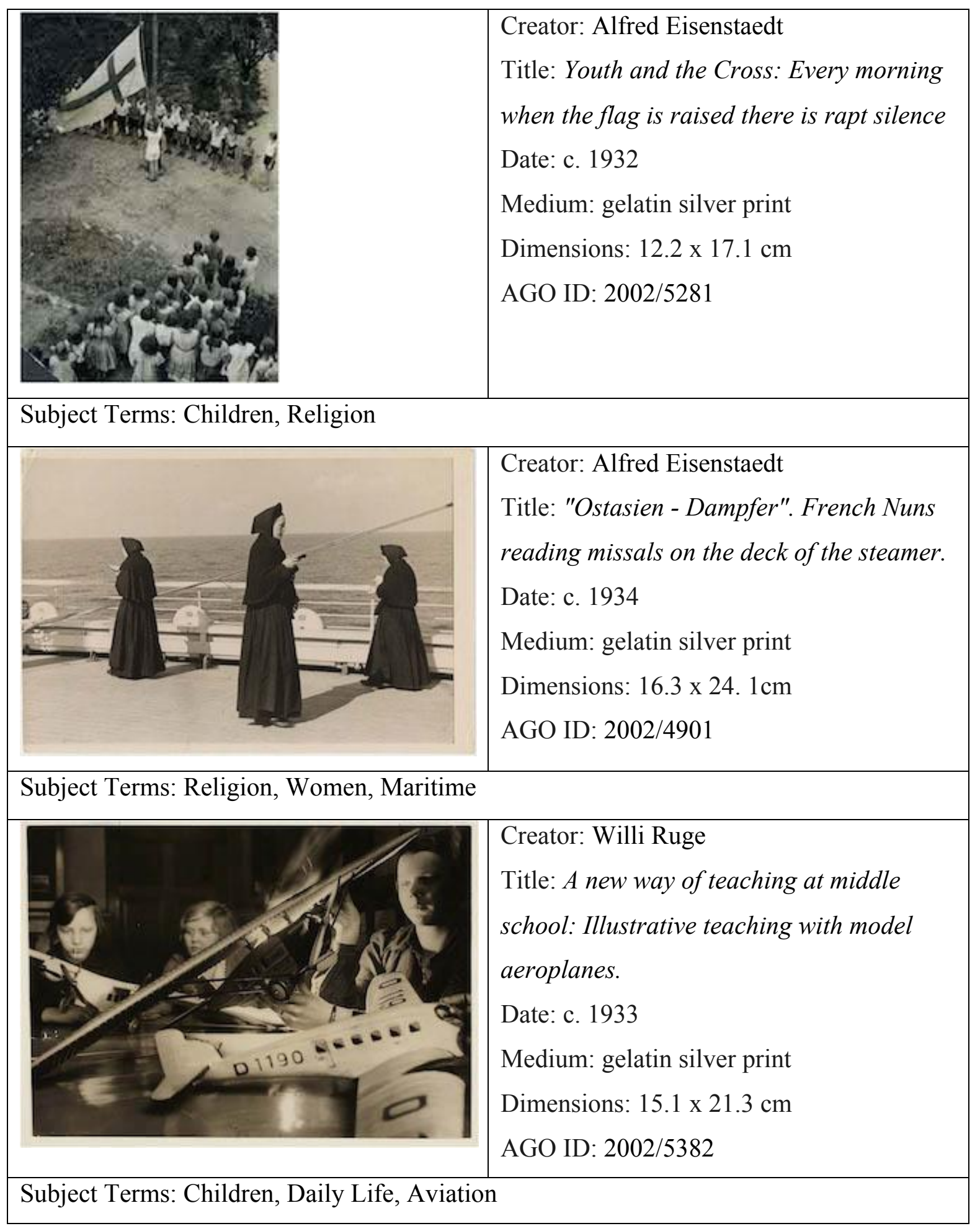




\begin{tabular}{|c|c|}
\hline & $\begin{array}{l}\text { Creator: Fritz Eschen } \\
\text { Title: Queen of the Air. World famous pilot } \\
\text { Elli Beinhorn renowned for her courageous } \\
\text { circum-aviation of the globe. } \\
\text { Date: c. } 1933 \\
\text { Medium: gelatin silver print } \\
\text { Dimensions: } 24.2 \text { x } 16.9 \mathrm{~cm} \\
\text { AGO ID: } 2002 / 5380\end{array}$ \\
\hline \multicolumn{2}{|c|}{ Subject Terms: Celebrity, Women, Aviation } \\
\hline & $\begin{array}{l}\text { Creator: Eisenhart } \\
\text { Title: Zeppelin } 129 \text { and Zeppelin } 127 \text { over } \\
\text { Berlin during their German tour. The air } \\
\text { giants fly above the Brandenburg gate. } \\
\text { Date: } 1936 \\
\text { Medium: gelatin silver print } \\
\text { Dimensions: } 24 \times 18 \mathrm{~cm} \\
\text { AGO ID: } 2002 / 5401\end{array}$ \\
\hline \multicolumn{2}{|l|}{ Subject Terms: Aviation } \\
\hline 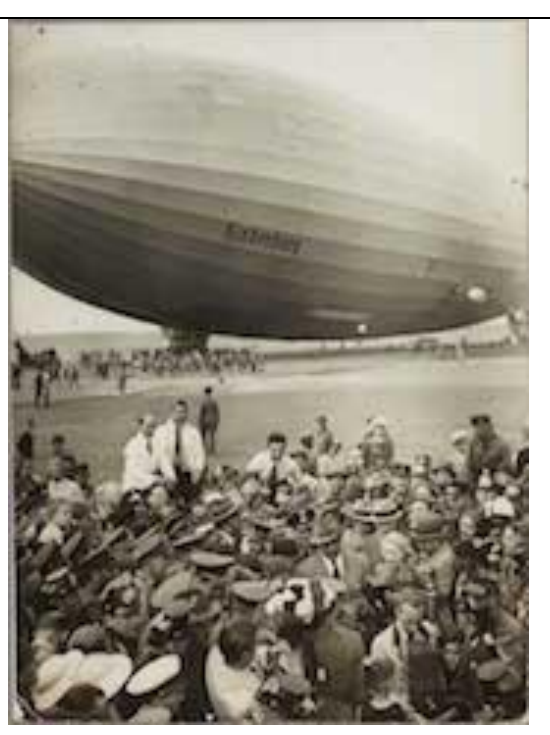 & $\begin{array}{l}\text { Creator: Associated Press of Berlin } \\
\text { Title: Max Schmeling returns home: } \\
\text { Schmeling, who defeated Joe Louis, "The } \\
\text { Brown Bomber", receives a rapturous } \\
\text { reception upon his arrival in the } \\
\text { Hindenburg in Frankfurt. } \\
\text { Date: } 1936 \\
\text { Medium: gelatin silver print } \\
\text { Dimensions: } 24.5 \times 18.1 \mathrm{~cm} \\
\text { AGO ID: } 2002 / 5405\end{array}$ \\
\hline
\end{tabular}




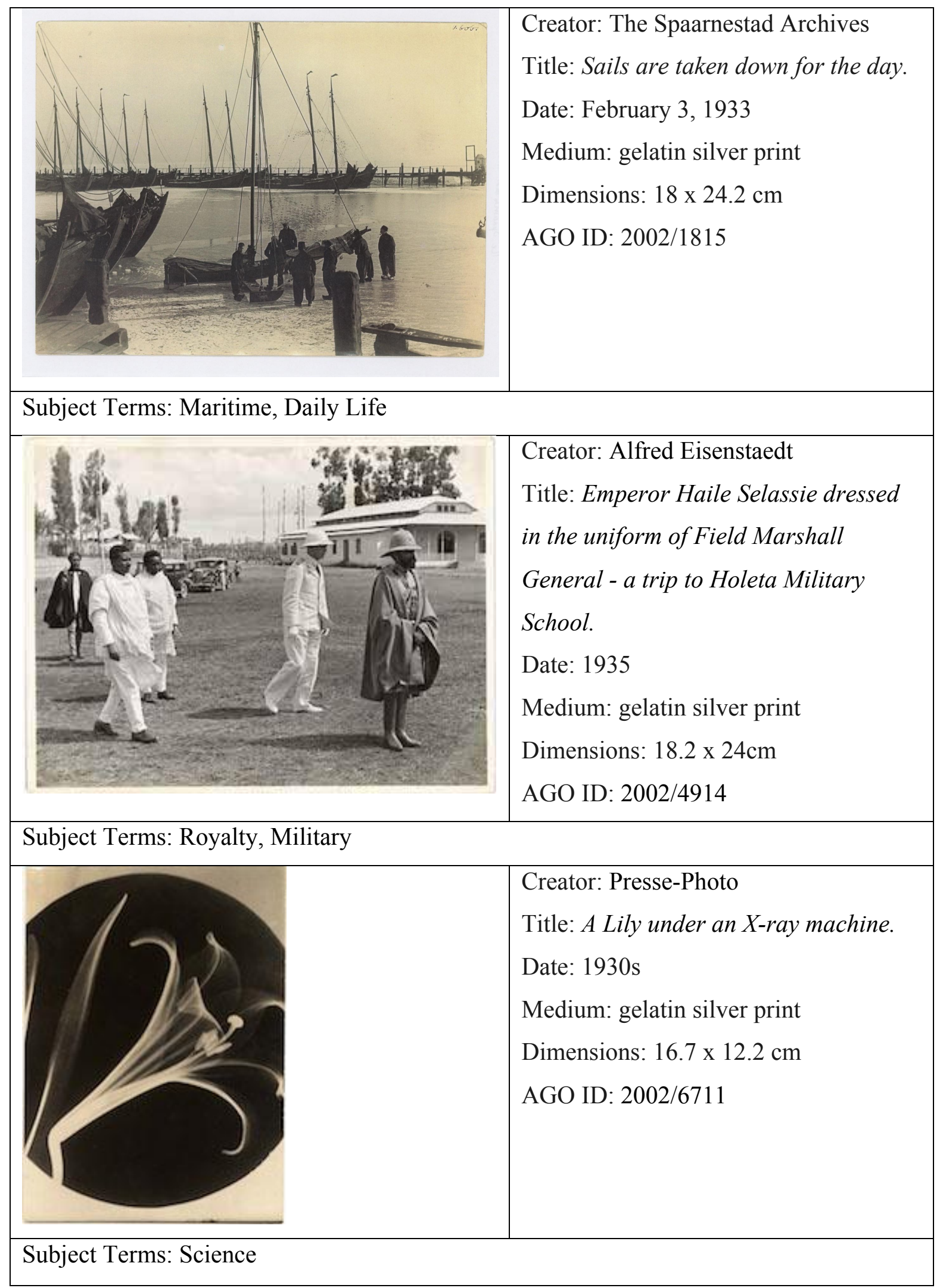




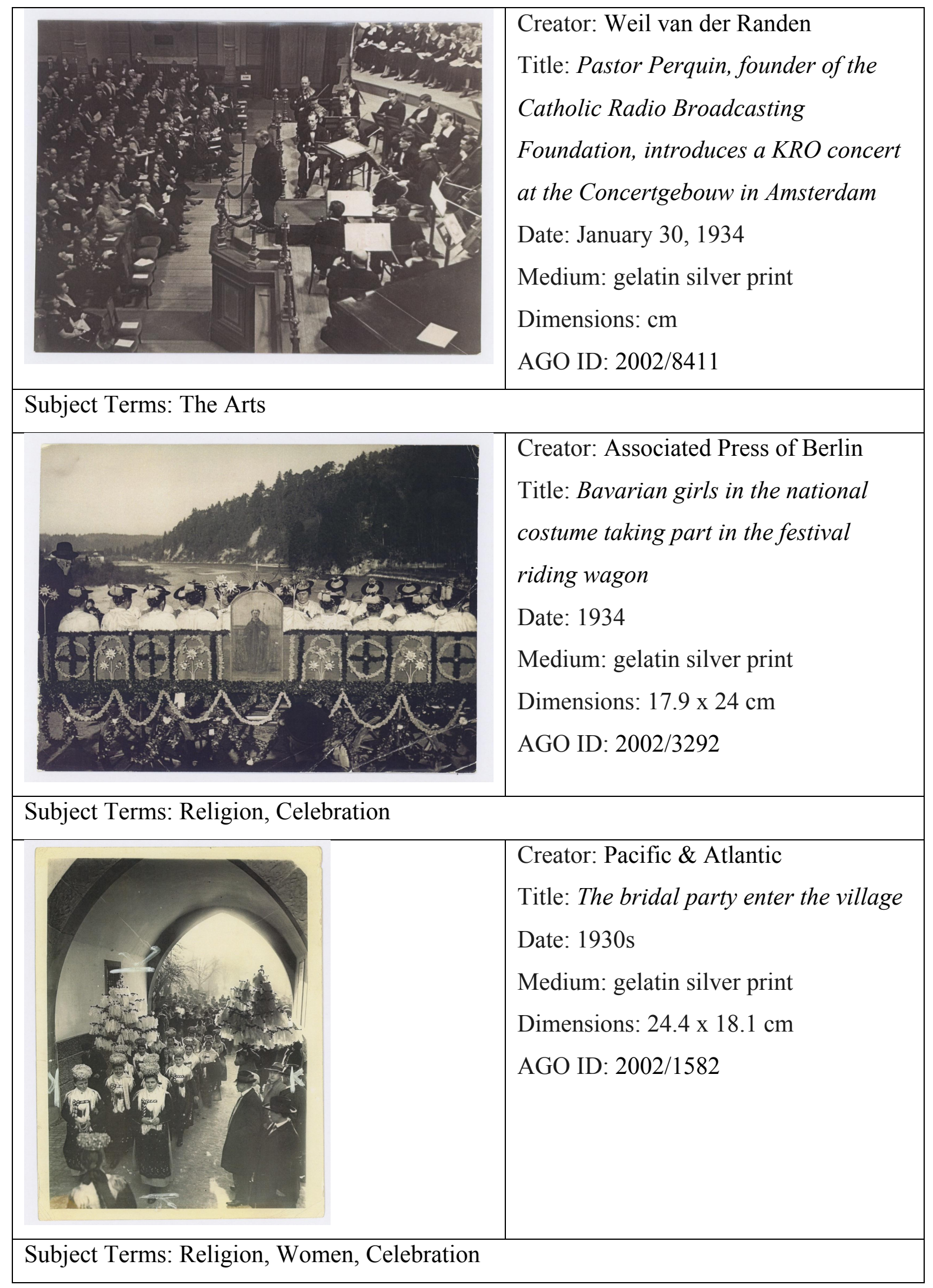




\begin{tabular}{|l|l|}
\hline & $\begin{array}{l}\text { Creator: Homan } \\
\text { Title: The Carnival Begins with a } \\
\text { Pageant of Absurd Figures } \\
\text { Date: 1930s } \\
\text { Medium: gelatin silver print } \\
\text { Dimensions: } 17.5 \mathrm{x} 24.3 \mathrm{~cm} \\
\text { AGO ID: 2002/2028 }\end{array}$ \\
\hline Subject Terms: Celebration, Daily Life & $\begin{array}{l}\text { Creator: Associated Press } \\
\text { Title: The End of a Gangster } \\
\text { Date: October 29, 1940 } \\
\text { Medium: gelatin silver print } \\
\text { Dimensions: 18.2 x 24 cm } \\
\text { AGO ID: 2002/423 }\end{array}$ \\
\hline Subject Terms: Criminology & $\begin{array}{l}\text { Creator: P. Roth } \\
\text { Title: While the administration of } \\
\text { Poland is being taken over by the } \\
\text { German authorities, the Polish Police } \\
\text { are working hand in hand with the } \\
\text { German Police. } \\
\text { Date: February 23, 1940 } \\
\text { Medium: gelatin silver print } \\
\text { Dimensions: } 24 \mathrm{x} 18.2 \mathrm{~cm} \\
\text { AGO ID: 2002/8530 }\end{array}$ \\
\hline
\end{tabular}




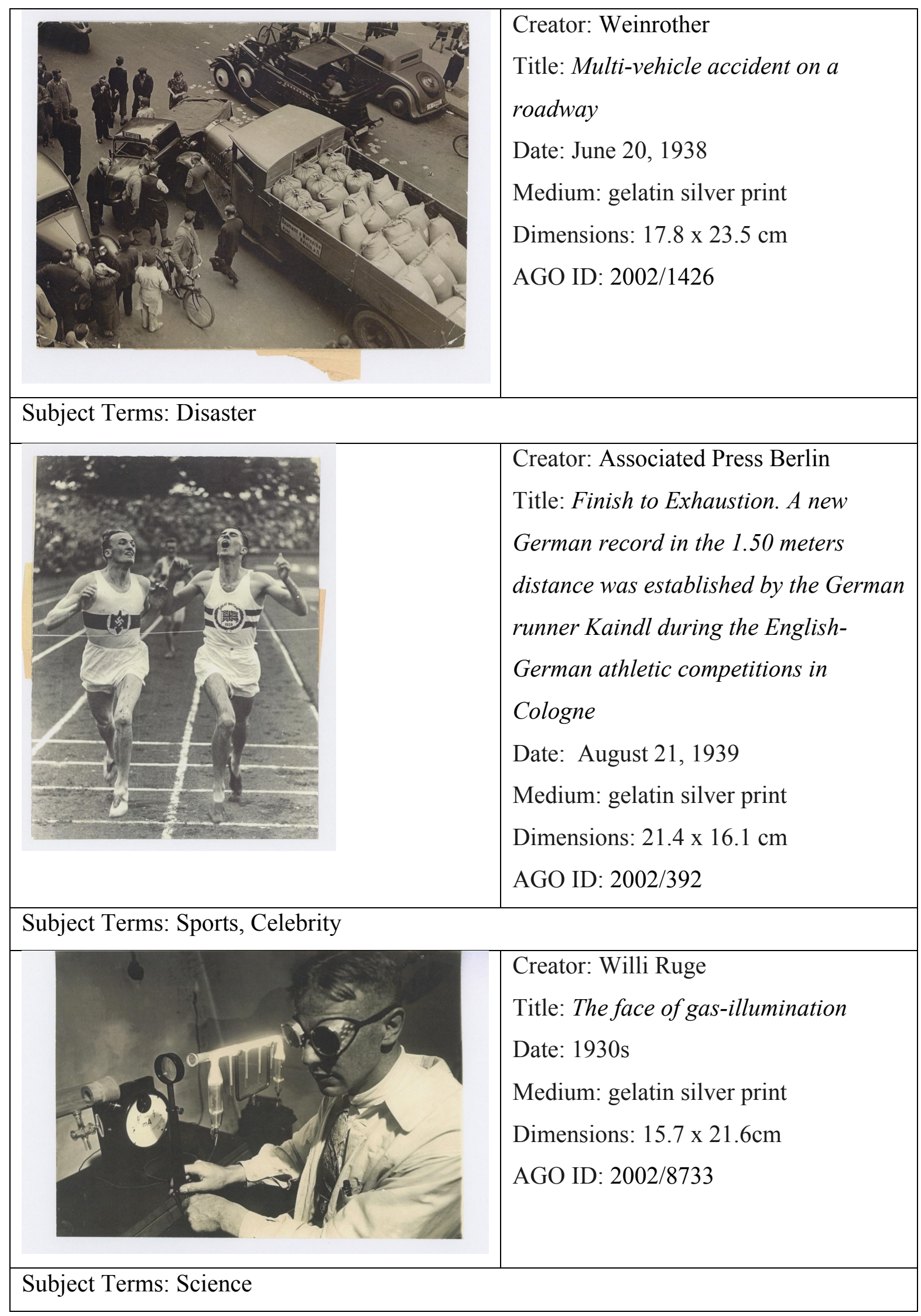


Appendix III: Index of Individuals with Biographical Materials

\author{
A \\ Eric Andres \\ Associated Press \\ B \\ Becker \& Maass \\ Hugo Bernatzik \\ Eva Besnyö \\ Leendert Blok \\ Eric Borchert \\ $\mathrm{C}$ \\ Robert Capa \\ Lynwood M. Chace \\ $\mathrm{D}$ \\ Leon Daniels \\ E \\ Lotte Errell \\ Alfred Eisenstaedt \\ Fritz Eschen \\ F \\ Else Fanter and Akademia \\ Mauricio Fresco \\ Theo Frey \\ G \\ Sonja Georgi \\ Rudolf Gotsche \\ John Gutmann \\ $\mathrm{H}$ \\ Sven Hedin \\ Joel Heinzelmann
}




\author{
Heinrich Hoffmann \\ Emil Otto Hoppé \\ Alfred Hugenberg \\ Hans Hubmann \\ J \\ Lotte Jacobi \\ Wolfram Junghans \\ K \\ George Karger \\ Keystone Agency \\ Ihee Kimura, \\ Zoltan Kluger \\ $\mathrm{L}$ \\ Erna Lendvai-Dircksen \\ Life magazine \\ Look magazine \\ $\mathrm{M}$ \\ Felix H. Man \\ Omar Oscar Marcus \\ Martin Munkácsi \\ Eckart Muthesius \\ $\mathrm{N}$ \\ Neofot \\ $\mathrm{P}$ \\ Pacific \& Atlantic \\ Federico Patellani \\ Karel Plicka \\ $\mathrm{R}$ \\ Willi Ruge \\ S \\ Lorenz Saladin
}




Walter Sanders
Eric Schaal
August Scherl
Max Schirner
Gotthard Schuh
Wolf Strache
T
Herbert Tichy
Hanns Tschira
U
Umbo
V
Heinz von Perckhammer
Willem Van de Poll
Van der Randen
W
Weltbild Verlag
Paul Wolff


Appendix IV: Klinsky I Box Location and Information

\begin{tabular}{|c|c|c|}
\hline Bay & Box Number & Box Name \\
\hline Bay 1 & $\mathrm{sb} 11$ & The 1930's Volume 1 \\
\hline Bay 1 & $\mathrm{sb} 12$ & The 1930's Volume 2 \\
\hline Bay 1 & $\mathrm{sb} 13$ & The 1930's Volume 3 \\
\hline Bay 1 & $\mathrm{sb} 14$ & The 1930's Volume 4 \\
\hline Bay 1 & $\mathrm{sb} 15$ & The 1930's Volume 5 \\
\hline Bay 2 & sb 1 & Agencies \& Photographers Volume 1 \\
\hline Bay 2 & $\mathrm{sb} 2$ & Agencies \& Photographers Volume 2 \\
\hline Bay 2 & sb 3 & Agencies \& Photographers Volume 3 \\
\hline Bay 2 & $\mathrm{sb} 4$ & Agencies \& Photographers Volume 4 \\
\hline Bay 2 & $\mathrm{sb} 5$ & Agencies \& Photographers Volume 5 \\
\hline Bay 2 & $\mathrm{sb} 6$ & Agencies \& Photographers Volume 6 \\
\hline Bay 2 & $\mathrm{sb} 7$ & Agencies \& Photographers Volume 7 \\
\hline Bay 2 & $\mathrm{sb} 8$ & Agencies \& Photographers Volume 8 \\
\hline Bay 2 & $\mathrm{sb} 9$ & Agencies \& Photographers Volume 9 \\
\hline Bay 2 & $\mathrm{sb} 10$ & Agencies \& Photographers Volume 10 \\
\hline Bay 2 & $\mathrm{sb} 11$ & Agencies \& Photographers Volume 11 \\
\hline Bay 2 & $\mathrm{sb} 12$ & Agencies \& Photographers Volume 12 \\
\hline Bay 2 & $\mathrm{sb} 13$ & Agencies \& Photographers Volume 13 \\
\hline Bay 2 & $\mathrm{sb} 14$ & Agencies \& Photographers Volume 14 \\
\hline Bay 2 & $\mathrm{sb} 15$ & Agencies \& Photographers Volume 15 \\
\hline Bay 2 & sb 16 & Agencies \& Photographers Volume 16 \\
\hline
\end{tabular}




\begin{tabular}{|c|c|c|}
\hline Bay 2 & $\mathrm{sb} 17$ & Agencies \& Photographers Volume 17 \\
\hline Bay 2 & $\mathrm{sb} 18$ & Agencies \& Photographers Volume 18 \\
\hline Bay 2 & $\mathrm{sb} 19$ & Agencies \& Photographers Volume 19 \\
\hline Bay 2 & $\mathrm{sb} 20$ & Agencies \& Photographers Volume 20 \\
\hline Bay 2 & $\mathrm{sb} 21$ & Agencies \& Photographers Volume 21 \\
\hline Bay 2 & $\mathrm{sb} 22$ & Agencies \& Photographers Volume 22 \\
\hline Bay 2 & $\mathrm{sb} 23$ & Agencies \& Photographers Volume 23 \\
\hline Bay 2 & $\mathrm{sb} 24$ & Agencies \& Photographers Volume 24 \\
\hline Bay 2 & $\mathrm{sb} 25$ & Agencies \& Photographers Volume 25 \\
\hline Bay 2 & $\mathrm{sb} 26$ & Agencies \& Photographers Volume 26 \\
\hline Bay 2 & $\mathrm{sb} 27$ & Agencies \& Photographers Volume 27 \\
\hline Bay 2 & $\mathrm{sb} 28$ & Agencies \& Photographers Volume 28 \\
\hline Bay 2 & $\mathrm{sb} 29$ & Agencies \& Photographers Volume 29 \\
\hline Bay 2 & $\mathrm{sb} 30$ & Agencies \& Photographers Volume 30 \\
\hline Bay 2 & $\mathrm{sb} 31$ & Agencies \& Photographers Volume 31 \\
\hline Bay 2 & $\mathrm{sb} 32$ & Associated Press of Berlin Volume 1 \\
\hline Bay 2 & $\mathrm{sb} 33$ & Associated Press of Berlin Volume 2 \\
\hline Bay 2 & $\mathrm{sb} 34$ & Associated Press of Berlin Volume 3 \\
\hline Bay 2 & $\mathrm{sb} 35$ & Associated Press of Berlin Volume 4 \\
\hline Bay 2 & $\mathrm{sb} 36$ & Associated Press of Berlin Volume 5 \\
\hline Bay 2 & $\mathrm{sb} 37$ & Associated Press of Berlin Volume 6 \\
\hline Bay 2 & sb 38 & Associated Press of Berlin Volume 7 \\
\hline Bay 2 & $\mathrm{sb} 39$ & Associated Press of Berlin Volume 8 \\
\hline Bay 2 & $\mathrm{sb} 40$ & Associated Press of Berlin Volume 9 \\
\hline Bay 2 & $\mathrm{sb} 41$ & Associated Press of Berlin Volume 10 \\
\hline
\end{tabular}




\begin{tabular}{|c|c|c|}
\hline Bay 2 & sb 42 & Associated Press of Berlin Volume 11 \\
\hline Bay 2 & sb 43 & Associated Press of Berlin Volume 12 \\
\hline Bay 2 & sb 44 & Associated Press of Berlin Volume 13 \\
\hline Bay 2 & sb 45 & Associated Press of Berlin Volume 14 \\
\hline Bay 2 & sb 46 & Gerd Baatz \\
\hline Bay 2 & sb 47 & L. Blok Volume 1 \\
\hline Bay 2 & sb 48 & L. Blok Volume 2 \\
\hline Bay 3 & sb 1 & Eric Borchert Volume 1 \\
\hline Bay 3 & sb 2 & Eric Borchert Volume 2 \\
\hline Bay 3 & sb 3 & Eric Borchert Volume 3 \\
\hline Bay 3 & sb 4 & Eric Borchert Volume 4 \\
\hline Bay 3 & sb 5 & Deutche Verlag Volume 1 \\
\hline Bay 3 & sb 6 & Deutche Verlag Volume 2 \\
\hline Bay 3 & sb 7 & Deutche Verlag Volume 3 \\
\hline Bay 3 & sb 8 & Alfred Eisenstaedt Volume 1 \\
\hline Bay 3 & sb 9 & Alfred Eisenstaedt Volume 2 \\
\hline Bay 3 & sb 10 & Alfred Eisenstaedt Volume 3 \\
\hline Bay 3 & sb 11 & Alfred Eisenstaedt Volume 4 \\
\hline Bay 3 & sb 12 & Alfred Eisenstaedt Volume 5 \\
\hline Bay 3 & sb 13 & Alfred Eisenstaedt Volume 6 \\
\hline Bay 3 & sb 14 & Alfred Eisenstaedt Volume 7 \\
\hline Bay 3 & sb 15 & Alfred Eisenstaedt Volume 8 \\
\hline Bay 3 & sb 16 & Alfred Eisenstaedt Volume 9 \\
\hline Bay 3 & sb 17 & Alfred Eisenstaedt Volume 10 \\
\hline
\end{tabular}




\begin{tabular}{|l|l|l|}
\hline Bay 3 & sb 18 & Alfred Eisenstaedt Volume 11 \\
\hline Bay 3 & sb 19 & Alfred Eisenstaedt Volume 12 \\
\hline Bay 3 & sb 20 & Alfred Eisenstaedt Volume 13 \\
\hline Bay 3 & sb 21 & Lotte Errell Volume 1 \\
\hline Bay 3 & sb 22 & Lotte Errell Volume 1 \\
\hline Bay 3 & sb 23 & Mauricio Fresco \\
\hline Bay 3 & sb 24 & Rud Gotsche \\
\hline Bay 3 & sb 25 & John Gutmann \\
\hline Bay 3 & sb 26 & E.O. Hoppé \\
\hline Bay 3 & sb 27 & Ihee Kimura \\
\hline Bay 3 & sb 28 & Dorien Leigh \\
\hline Bay 3 & sb 29 & Oscar Markus \\
\hline Bay 3 & sb 30 & Pix Publishing Volume 1 \\
\hline Bay 3 & sb 31 & Pix Publishing Volume 2 \\
\hline Bay 3 & sb 32 & Pix Publishing Volume 3 \\
\hline Bay 3 & sb 33 & Pix Publishing Volume 4 \\
\hline Bay 3 & sb 34 & Pix Publishing Volume 5 \\
\hline Bay 3 & sb 35 & Pix Publishing Volume 6 \\
\hline Bay 3 & sb 36 & Pix Publishing Volume 7 \\
\hline Bay 3 & sb 37 & Pix Publishing Volume 8 \\
\hline Bay 3 & sb 38 & Presse-Photo Agency Volume 1 \\
\hline Bay 3 & sb 39 & Presse-Photo Agency Volume 2 \\
\hline Bay 3 & sb 40 & Presse-Photo Agency Volume 3 \\
\hline Bay 3 & sb 41 & Presse-Photo Agency Volume 4 \\
\hline Bay 3 & sb 42 & Presse-Photo Agency Volume 5 \\
\hline
\end{tabular}




\begin{tabular}{|c|c|c|}
\hline Bay 3 & sb 43 & Presse-Photo Agency Volume 6 \\
\hline Bay 3 & sb 44 & Presse-Photo Agency Volume 7 \\
\hline Bay 3 & sb 45 & Presse-Photo Agency Volume 8 \\
\hline Bay 3 & sb 46 & Presse-Photo Agency Volume 9 \\
\hline Bay 3 & sb 47 & Presse-Photo Agency Volume 10 \\
\hline Bay 3 & sb 48 & Presse-Photo Agency Volume 11 \\
\hline Bay 4 & sb 1 & Presse-Photo Agency Volume 12 \\
\hline Bay 4 & $\mathrm{sb} 2$ & Presse-Photo Agency Volume 13 \\
\hline Bay 4 & sb 3 & Presse-Photo Agency Volume 14 \\
\hline Bay 4 & sb 4 & Presse-Photo Agency Volume 15 \\
\hline Bay 4 & sb 5 & Presse-Photo Agency Volume 16 \\
\hline Bay 4 & sb 6 & Presse-Photo Agency Volume 17 \\
\hline Bay 4 & sb 7 & Presse-Photo Agency Volume 18 \\
\hline Bay 4 & sb 8 & Presse-Photo Agency Volume 19 \\
\hline Bay 4 & sb 9 & Presse-Photo Agency Volume 20 \\
\hline Bay 4 & sb 10 & Presse-Photo Agency Volume 21 \\
\hline Bay 4 & sb 11 & Presse-Photo Agency Volume 22 \\
\hline Bay 4 & sb 12 & Presse-Photo Agency Volume 23 \\
\hline Bay 4 & sb 13 & Supplementary Volume 1 \\
\hline Bay 4 & sb 14 & Supplementary Volume 2 \\
\hline Bay 4 & sb 15 & Supplementary Volume 3 \\
\hline Bay 4 & sb 16 & Supplementary Volume 4 \\
\hline Bay 4 & sb 17 & P. Roth Volume 1 \\
\hline Bay 4 & sb 18 & P. Roth Volume 2 \\
\hline
\end{tabular}




\begin{tabular}{|l|l|l|}
\hline Bay 4 & sb 19 & Willi Ruge \\
\hline Bay 4 & sb 20 & Ruge Supplementary Volume 1 \\
\hline Bay 4 & sb 21 & Ruge Supplementary Volume 2 \\
\hline Bay 4 & sb 22 & Ruge Supplementary Volume 3 \\
\hline Bay 4 & sb 23 & Schmidt-Schaumburg \\
\hline Bay 4 & sb 24 & Walter Sussman/Lueders Supplementary Volume \\
\hline Bay 4 & sb 25 & Sussman/Lueders Volume 1 \\
\hline Bay 4 & sb 26 & Sussman/Lueders Volume 2 \\
\hline Bay 4 & sb 27 & Ilse Steinhoff \\
\hline Bay 4 & sb 28 & Transatlantic Volume 1 \\
\hline Bay 4 & sb 29 & Transatlantic Volume 2 \\
\hline Bay 4 & sb 30 & Transatlantic Volume 3 \\
\hline Bay 4 & sb 31 & van de Poll Volume 1 \\
\hline Bay 4 & sb 32 & van de Poll Volume 2 \\
\hline Bay 4 & sb 33 & van der Randen \\
\hline Bay 4 & sb 34 & Eisenstaedt,Walter/Lueders, Presse-Photo- flat file \\
\hline Bay 4 & sb 35 & Eisenstaedt-flat file \\
\hline Bay 4 & sb 36 & Eisenstaedt-flat file \\
\hline Bay 4 & sb 37 & Eisenstaedt-flat file \\
\hline Bay 4 & sb 38 & Eisenstaedt-flat file \\
\hline Bay 4 & sb 39 & Eisenstaedt- flat file \\
\hline Bay 4 & sb 40 & Eisenstaedt, Ruge, Steinhoff, Roth- flat file \\
\hline Bay 4 & sb 40a & Eisenstaedt, Borchert, Walter/Lueders, Hellman-flat file \\
\hline Bay 4 & sb 41 & Borchert, Associated Press, etc- flat file \\
\hline Bay 4 & sb 42 & Presse-Photo, Eisenstaedt, Hellmann, Walter/Lueders- flat file \\
\hline
\end{tabular}


Borchert, Associated Press Berlin, P. Roth, Fritz, Eschen,

\begin{tabular}{l|l|l} 
Bay 4 & sb 43 & Mobius, Fotoaktuell, Steinhoff- flat file
\end{tabular} 